NBER WORKING PAPER SERIES

\title{
DOES ILLIQUIDITY ALTER CHILD LABOR \\ AND SCHOOLING DECISIONS? \\ EVIDENCE FROM HOUSEHOLD RESPONSES TO ANTICIPATED CASH TRANSFERS IN SOUTH AFRICA
}

\author{
Eric V. Edmonds \\ Working Paper 10265 \\ http://www.nber.org/papers/w10265 \\ NATIONAL BUREAU OF ECONOMIC RESEARCH \\ 1050 Massachusetts Avenue \\ Cambridge, MA 02138 \\ January 2004
}

I am grateful to Andrew Foster, John Giles, Steven Haider, Anna Lusardi, Douglas L. Miller, Nina Pavcnik, Andrew Samwick, Doug Staiger, John Strauss, Ken Swinnerton, and seminar participants at INRA/DELTA, Michigan, Michigan State, NEUDC, Oregon, Toulouse for detailed comments and encouragement. I appreciate the able research assistance of Steve Cantin and Andreea Gorbatai. Financial support for this project was provided by the Nelson A. Rockefeller Center at Dartmouth College and a Rockefeller-Haney Grant. Correspondence to: Eric Edmonds, 6106 Rockefeller Hall, Dartmouth-Economics, Hanover NH 03755, USA, eedmonds@dartmouth.edu. First draft entitled "Is Child Labor Inefficient? Evidence from Large Cash Transfers," May 2002. The views expressed herein are those of the authors and not necessarily those of the National Bureau of Economic Research.

(C2004 by Eric V. Edmonds. All rights reserved. Short sections of text, not to exceed two paragraphs, may be quoted without explicit permission provided that full credit, including (C) notice, is given to the source. 
Does Illiquidity Alter Child Labor and Schooling Decisions? Evidence from Household Responses to Anticipated Cash Transfers in South Africa

Eric V. Edmonds

NBER Working Paper No. 10265

January 2004

JEL No. J22, J82, O16, H55

\begin{abstract}
This study considers the response of child labor supply and schooling attendance to anticipated social pension income in South Africa. For black households in South Africa, the social pension is large, highly anticipated, and shared across generations. Moreover, pension benefits are largely determined by age in South Africa's extremely poor black population, and this study uses the age discontinuity in the pension benefit formula for identification. The South African social pension thus presents an unusually clean test of the applicability of the Life-Cycle/Permanent Income model to child labor and schooling decisions in developing countries. In the present case, the data support the theory that liquidity constraints contribute to high levels of child labor. When households become eligible for the social pension in South Africa, the resulting increase in household non-labor income is associated with a sizeable decline in child labor and increases in schooling. Changes in child labor and schooling are largest among pensioners with little formal education. This finding suggests that the current emphasis in development policy of addressing child labor by attacking labor demand may be misdirected.
\end{abstract}

Eric V. Edmonds Department of Economics Dartmouth College 6106 Rockefeller Hall Hanover, NH 03755 and NBER eedmonds@dartmouth.edu 


\section{Introduction}

Few issues in developing countries draw more public attention than child labor.

Governments in both rich and poor nations battle child labor in the developing world largely with policies aimed at mitigating the demand for child labor. This policy reflects the view that families choose to send their children to work, because the return to child labor is greater than that of the alternative activities of the child such as schooling as discussed in Shultz (1960). If (as implied by Becker 1975 and made explicit in Baland and Robinson 2000) child labor is higher than families desire because of liquidity constraints, lowering the demand for child labor may only increase the need to send children to work and may be punitive against those in most need of assistance. ${ }^{1}$ Moreover, increases in household income through economic growth and development can ameliorate child labor associated with liquidity constraints. However, growth may raise the earnings opportunities open to children as well. Thus understanding the role of liquidity constraints in child labor supply is critical to understanding how child labor will change with economic development. This study examines the role liquidity constraints play in child labor supply and schooling decisions by examining how these decisions respond to receipt of large, anticipated increases in household income.

Even for consumption smoothing, the evidence on the significance of liquidity constraints is decidedly mixed in both high and low income countries (Browning and Lusardi 1996). Formal financial institutions are poorly developed in general in low-income countries (Townsend 1995), but despite this, poor agricultural households within low-income countries appear to be effective in smoothing their consumption over predictable, seasonal variation in agricultural incomes as if they faced perfect credit markets (e.g. Paxson 1993 and Jacoby and Skofias 1998). The evidence from unanticipated changes in income is varied, but a number of studies find qualified support for the permanent income hypothesis by examining the household's marginal propensity to consume from income shocks attributable to rainfall (e.g. Paxson 1992). Morduch (1994, 1995,

\footnotetext{
${ }^{1}$ The Basu and Van (1998) model is an extreme version of this model where there are no capital markets, and children work if and only if their income is required to meet basic subsistence needs.
} 
1999) emphasizes that credit constrained household may turn to mechanisms other than borrowing to smooth consumption. Possible mechanisms for consumption smoothing are variation in adult (Kochar 1999, Frankenberg, Smith, and Thomas 2003) or child labor (Jacoby and Skoufias 1997). Indeed, three recent papers have found a strong relationship between unanticipated income shocks and child labor (Beegle, Dehejia, and Gatti 2003, Guarcello, Mealli, and Rosati 2003, and Yang 2003).

Household responses to unanticipated changes in income are of considerable interest in their own right, but four issues complicate using shocks to examine the role of liquidity constraints in child labor supply and schooling decisions. First, economic shocks will be associated with changes in the relative return to child time in various activities. For example, recovering from a flood may raise local wage rates as the community recovers; it may lower them as a consequence of a lost harvest; or it may cause the school to close. Moreover, since most children work within their own homes, a within community association between child labor or schooling's response to the shock and household assets may reflect how assets and child time enter into the household's production function (as modeled formally in Jacoby's 1994 adaptation of the Ben-Porath 1967 model). Second, unanticipated changes in household income can be insured against even in the presence of liquidity constraints. Thus, studies of household responses to unanticipated changes in income confound failures in insurance mechanisms with liquidity constraints, and it seems difficult to separately identify each. Third, the extent to which a change in family income is unexpected is difficult for the econometrician to identify. A perennial question in studies of crop shocks for example is the extent to which the disaster is unanticipated. Fourth, even if a researcher can separate the predictable and unpredictable parts of household income, it is never clear if this separation corresponds to what the family decisionmaker perceives. For these latter two reasons, recent tests of the consumption smoothing lifecycle/permanent income hypothesis models have tended to examine household responses to well-defined, anticipated income changes (e.g. Parker 1999, Souleles 1999 and 2002). 
The anticipated income increase explored in this paper comes from a large social pension program in South Africa. The black population of South Africa is substantially poorer than the white population. Hence, when the relatively meager white Old Age Pension (OAP) program was extended to other South Africans at the end of apartheid, the social pension became a large cash transfer. There is a means test in the OAP that binds for most white households but affects few black households (Case and Deaton 1998). Thus, the primary determinant of the cash transfer is the age of the beneficiary, and there is little uncertainty about the benefit level (Alderman 1999). Moreover, the South African social pensions are so large (for black households, the 1999 benefit of 520 Rand per month more than doubles black median per capita income) that they are well-known and highly anticipated by recipients (Lund 1993). Further, black South African households are typically multi-generational, so there is ample scope for this pension income to be shared with children. In fact, other studies of the OAP have documented sharing of the pension benefit with co-resident adults (Lund 1993, Bertrand, Mullainathan, and Miller 2003), across households (Jensen 2004), and with children (Duflo 2000 and 2003). Consequently, the South African social pension seems an unusually clear environment in which to consider the relationship between child labor, schooling, and liquidity constraints.

This study examines the response of child labor to the timing of income by comparing child labor supply and schooling in households that are eligible for the OAP to households that are not eligible. The empirical work in this paper employs a regression discontinuity design to address the problem that households with elders eligible for the pension are older and may differ in systematic ways from households without eligible elders. This paper finds large changes in child labor and schooling when anticipated income is received, a finding consistent with the presence of liquidity constraints. Once households become age eligible for the pension income, child labor declines and schooling increases. Declines in child labor are largest in market work such as work for wages, work on the family farm, or work in the household business. School attendance increases with pension eligibility, and school attainment is increasing in the time that 
the household has been eligible for the pension. The effect of pension eligibility on child labor and schooling appears to vary with the gender of the elder. In general, child labor decreases and schooling increases more when men reach eligibility than when women become pension eligible although the difference between men and women elders is not statistically significant in every specification. Male pension eligibility is associated with an approximately 35 percent decline in hours worked per week and a rise in school attendance to almost 100 percent. These findings imply that because of male pension eligibility 23,000 children are attending school who would otherwise not and over 180 million fewer hours were worked by children in a 1999 .

This finding of liquidity constraints in the child labor decision supports the argument that the high levels of child labor in poor countries may reflect market imperfections associated with poverty rather than the families decision that the relative return to child labor is higher. Corroborating evidence for this study is available from Jacoby and Skofias (1997), Beegle, Dehejia, and Gatti (2003), Guarcello, Mealli, and Rosati (2003), and Yang (2003) who find that schooling and child labor supply appear to be important coping mechanisms in the household's response to unanticipated changes in income as well. Existing child labor programs directed at curtailing labor demand may be misdirected, and punitive, income-reducing policies such as trade sanctions designed to punish counties with high levels of child labor have the potential to increase child labor. ${ }^{2}$

The next section of the paper presents a model child labor where liquidity constraints induce higher levels of child labor than are optimal. Section 3 describes the old age pension and the identification strategy. Section 4 presents the results. Section 5 discusses several factors that may influence the interpretation of the results in this study including measurement error in age, endogenous household composition, age-discontinuities at pension ages absent the pension

\footnotetext{
${ }^{2}$ Basu and Van (1998) point out that if labor demand mechanisms were effective in eliminating child labor, there may be general equilibrium effects that raise adult wages enough to eliminate the household's desire to send children to work. Thus, the argument that attacking labor demand may only serve to increase child labor assumes that these labor demand oriented policies will not curtail child labor enough to induce these general equilibrium wage effects. Ranjan (2001) is a more formal development of this argument in the context of liquidity constraints.
} 
program such as might be caused by formal retirement or cohort-targeted child labor or schooling programs, and alternatives to liquidity constraints to explain timing of income effects on child labor and schooling. Section 6 concludes.

\section{Liquidity constraints and child labor - theory}

The basic model of Baland and Robinson (2000) has a single household decision-maker (a parent) who makes child labor and schooling decisions after making other household income decisions. The parent lives two periods. In the first period, the parent chooses savings $s$ and the fraction of child time spent working, $h . m_{1}$ is the household's income each period from sources other than child labor. Wages from working are normalized to 1 . Thus, consumption in the first period is: $c_{1}=m_{1}+h-s$. In the second period, in addition to the parent's income $m_{2}$, the parent receives the savings income and gives a bequest $b$ to the child: $c_{2}=m_{2}+s-b \cdot{ }^{3}$ Parental utility depends on consumption in period 1 and 2 as well as the well being of the child: $U_{p}\left(c_{1}, c_{2}, U_{c}\left(w_{c}\right)\right)$. Child well-being depends on the return to the time spent not working, $z(1-h)$, and income from bequests: $w_{c}=z(1-h)+b$.

If savings and bequests are not zero, then household chooses child labor so that marginal cost in terms of foregone consumption today due to decreased child labor exactly equals the additional return to the child of foregoing child labor: $z^{\prime}(1-h)=1$. Thus, child labor is privately efficient in the Baland and Robinson framework. If income is higher in the second period than in the first, child labor supply is unaffected. The household merely adjust savings. However, with liquidity constraints, the household cannot move resources between periods. ${ }^{4}$ Hence, child labor

\footnotetext{
${ }^{3}$ Adding an interest rate, discount rate, and (later) altruism parameter to the model does not affect the basic intuition of the test in this paper. Hence, they have been omitted from this presentation for simplicity.

${ }^{4}$ Either the presence of liquidity constraints or constraints on bequests can generate inefficiencies. Without bequests, children cannot compensate parents for the foregone consumption that comes from decreasing child labor. Hence, a failure to observe child labor responses to the timing of income does not necessarily imply that child labor is privately efficient, because the timing of income should have no effect on bequests although permanent income obviously will. Similarly, the observed levels of child labor after the relaxation of liquidity constraints are not necessarily privately efficient.
} 
supply in period one depends on the household's marginal utility of consumption in period one, and the resulting educational investments will be lower than in the equilibrium without liquidity constraints: $z^{\prime}(1-h)>1$. Child labor is inefficiently high from the household's perspective. ${ }^{5}$

In Baland and Robinson's model, identifying an income elasticity of child labor supply is indicative of a constraint on liquidity or bequests. However, the fact that child labor is income elastic is not sufficient for testing the efficiency of child labor in a more general model of child labor as in Becker (1965) or Bommier and Dubois (2003). First, leisure or education may be a normal good in parental preferences. Higher income thereby may lead to increases in leisure and education. Thus, to test for liquidity constraints in child labor, identification needs to be based on the timing of income. ${ }^{6}$ Second, the source of variation in the timing of income must not arise from the same household decision-making process that determines child labor supply. For example, Jacoby and Skoufias (1997) show that child labor supply and household income both vary with agricultural seasons. This could generate misleading results in identifying liquidity constraints, because changes in the value of child time outside of schooling coincide with changes in income, independent of any effect of expected seasonal variation in income on child labor. Third, the variation in the timing of income must be foreseeable to both the econometrician and the household. For the test of liquidity constraints posited here, the variation in the timing of income must reflect the variation perceived by the household decision-maker. A mismatch between the econometrician's understanding of predictable variation in the timing of income and the household's may yield false evidence of liquidity constraints if the income that appears anticipated to the econometrician is unanticipated by the household.

The timing of income influences child labor supply with liquidity constraints, because the household's inability to move resource between periods causes time allocation decisions to

\footnotetext{
${ }^{5}$ Baland and Robinson (2000) show that these results for savings and bequests also hold under reciprocal altruism when children value the well-being of their parents.

${ }^{6}$ There may still be a slight income effect associated with the timing of income because of the household's present value calculation. For example, if a million dollars today has a slightly higher present value than a million dollars tomorrow. The assumption in this paper is that the magnitude of this income effect based on timing is small.
} 
depend on the household's marginal utility of consumption. In a more general model, there are a number of other ways in which liquidity constraints may cause higher levels of child labor. For example, households might under-invest in child nutrition because of liquidity constraints, lowering the child's productivity in school. Improved nutrition as a result of receipt of the cash transfer (e.g. Duflo 2003) may then increase the return to schooling and lower child labor. Alternatively, liquidity constraints could limit the (in or out) migration of household members. Changes in household structure as a result of the anticipated receipt of income (e.g. Edmonds, Mammen, and Miller 2003) may then lower the demand for child labor within the household. One can imagine several other mechanisms through which liquidity constraints affect child labor supply other than through the direct effect of income on child labor. The possibility of these other mechanisms means that the results of this study cannot be interpreted as reflecting the direct effect of income itself. Nevertheless, to the extent that liquidity constraints cause these other factors to respond to the timing of income, these other factors are merely the mechanisms through which liquidity constraints generate higher levels of child labor than would be implied by the relative return to child labor. In this way, the model of Baland and Robinson and the results of the test in this paper can be interpreted as reduced form evidence of changes in child labor from relaxing liquidity constraints rather than as an identification of the mechanism through which liquidity constraints influence child labor supply.

\section{Testing for liquidity constraints in child labor decisions - an application}

\subsection{The Old Age Pension Program (OAP)}

The OAP in South Africa provides a good setting to explore whether the economic activities of children depend on the timing of increases in household income. The collapse of the apartheid system in the early 1990's brought (among other things) the extension of the white pension program to elderly blacks. This caused a dramatic increase in the pension receipts of almost all elderly blacks. Historically, blacks received only a fraction of the state pension that whites received, but by 1994 most blacks and whites eligible for the pension were receiving 
comparable amounts. The maximum benefit in 1999 was 520 Rand per month (about \$3 a day),

122 percent of the median per capita monthly household income of blacks in 1999.

The OAP has four important attributes that make it useful for this study. First, the pension does not depend on the activities of other household members. ${ }^{7}$ Hence, the pension itself does not create any incentive to change household composition or alter the activities of household members in order to receive the pension. Second, there is a means test in the pension formula that is important in the white population, but in practice its impact on benefit determination for black South Africans is minimal because of the relative depravation of the black population. ${ }^{8}$ Third, absent the means test, the age of co-resident household members determines whether the household is eligible for the pension. A woman is pension eligible if she is age 60 or older. A man is pension eligible at age 65 or older. Thereby, the timing of the income receipt and the magnitude of the cash transfer is easily identified for both the econometrician and the household. Fourth, it is not unusual for a pension eligible grandparent to reside with a grandchild in black South African households. Hence, there is ample scope for the sharing of pension income with co-resident children and their parents, and evidence of this sharing permeates the academic literature on the OAP (Lund 1993, Case and Deaton 1998, Bertrand, Mullainathan, and Miller 2003, Duflo 2003).

\footnotetext{
${ }^{7}$ The pension benefit formula explicitly does not consider pension income paid to an elder's spouse as well.

${ }^{8}$ A number of authors have observed that the means-test does not bind for most black African households (Case and Deaton (1998), Alderman (1999), Case (2001), Jensen (2002), Duflo (2003), and Bertrand, Mullainathan, and Miller (2003)). While these studies work with data from 1993, the means-test in the pension benefit formula has not changed substantively between 1993 and 1999, and the income at which the means-test begins has increased since 1993. The means-test is based on the personal wage income of the recipient, but most elder blacks do not pay income taxes and thereby have no incentive to declare income for the calculation of the means-test. In the South African tax code, individuals age 65 and older do not pay income tax so long as their personal income is below R47, 222 per year. Less than 9 percent of the control group data in this study report total household income at or above R47, 222. Even if reported, relatively few elder blacks report incomes near the pension age which are high enough to be affected by the means-test, and in the data used in this study all but 4 percent of pension recipients report total household income in a category at or above the maximum pension benefit of 520 Rand per month. The means-test only begins when official incomes exceed 30 percent of the maximum grant. It does not include the income of other household members other than the spouse, and it explicitly does not include spouse's pension income.

Consequently, if the means test were implemented regardless of an individual's tax status, it would only affect pensioners with a formal sector income above 156 Rand per month. When the dataset used in this study is restricted to households in the control group, only 42 percent of households have per capita incomes above 156 Rand per month when all sources of income are considered (most of which would not be reported to tax authorities).
} 


\subsection{Empirical methodology}

The response of child labor supply to the timing of income is tested by comparing the labor supply of children in households with a pensioner to children in households with an elder that is not yet pension eligible. The influence of the gender of the pensioner on the link between the timing of pension income and child labor is also examined.

Since pensioners are not randomly distributed among households, the comparison of child labor in households with pensioners to child labor in households where the elder is not yet pension eligible raises two concerns. First, take-up of the pension may be an endogenous household decision. For example, Case and Deaton (1998) find that households receiving the pension are poorer on average. If children are more likely to work in poorer households, then child labor may be positively associated with pension take-up. This endogenous pension take-up problem is addressed by focusing on pension eligibility rather than actual take-up. For black households, pension eligibility depends on the pensioner's age rather than any household decisions. Women become eligible for the OAP at age 60. Men become eligible at age 65 . Hence, the test for liquidity constraints affecting child labor supply comes from comparing child labor supply in households with a man at or above age 65 or woman at or above 60 to child labor supply in households with a younger elder.

By focusing on eligibility rather than pension take-up, the results of this paper can be interpreted as reduced form regressions for a model where pension income is instrumented by eligibility. The income data associated with the child labor data used in this study are poor; estimating the structural model is infeasible. ${ }^{9}$ Moreover as discussed in section 2, there is no reason in examining liquidity constraints to restrict the timing of income to influence child labor through the direct effect of income on child labor alone. Indirect effects can still identify liquidity constraints. Nevertheless, there needs to be a link between pension eligibility and

\footnotetext{
${ }^{9}$ The questionnaire collects income by asking for total household income in the last year. Rather than recording an income amount, the survey asks the respondent to select one of several broad categories (60 percent of the population falls in one of the five categories), and 5 percent of the sample used in this study does not respond to the income question.
} 
household income in order to interpret the results of this study in terms of liquidity constraints. Several studies using other datasets document a link between pension eligibility and household income in black South African households. ${ }^{10}$ In the dataset used in this study, 80 percent of eligible households report take-up of the pension. The link between household income and pension eligibility in the data used in this study is discussed in detail in Appendix 1. The probability that the household reports receiving pension income increases by 600 percent with pension eligibility, and the probability that a household reports an income at or above the pension amount of 520 Rands per month rises by 12 percentage points if at least one co-resident elder is pension eligible (t-statistic 8.167). Henceforth, when considering the effect of pension eligibility on child labor, pension eligibility will be treated as reflecting additional household income.

The second main concern raised by the non-randomness of pension income is that households with pensioners may differ systematically from non-pension households. In particular, households with pensioners are likely to be older on average than are households without a pensioner and are more apt to contain multiple generations. Comparing children who co-reside with an elderly person to those who do not is problematic, because the presence of an elderly individual may influence the allocation of a child's time other than through income. For example, an elder may need care, bringing additional household obligations to children. Alternatively, an older person may take over some of the duties performed by children.

These problems influence the empirical work in two ways. First, the sample is limited to children that co-reside with an elder. In particular, the sample is restricted to children that coreside with a person between the ages of 50 and 75 . Restricting the sample in this manner means that the effect of a pensioner of a given gender is identified by comparing the effect of a person who is near but below pension age to a person who is of pension age (e.g. the effect of having a

\footnotetext{
${ }^{10}$ See Edmonds and others (2003) for the 1996 South African census and Case and Deaton (1998) for evidence from a 1993 household survey.
} 
64 year old man relative to a 66 year old man). This type of identification is used in Bertrand and others (2003) and Case (2001).

An obvious concern in this approach is that the pension indicator may capture age trends in addition to the effect of pension income on child labor. ${ }^{11}$ Thus, this study allows for differences in child labor with the age of the elder by including a series expansion in the ages of the oldest male and female in the household in each regression. The basic regression approach is thus:

$$
H_{i j}=\beta_{0}+\beta_{1} P E F_{i}+\beta_{2} P E M_{i}+\beta_{3} P E F_{i} * P E M_{i}+\pi\left(A O M_{i}, A O F_{i}\right)+\varepsilon_{i j}
$$

where $H$ is the labor supply of child $j$ in household $i, P E F$ indicates the presence in the household of a female who is at or above age 60 (and thus pension eligible), PEM indicates the presence in the household of a male who is age 65 or older (pension eligible), $P E F^{*} P E M$ allows for an interaction of these two, and $\pi\left(A O M_{i}, A O F_{i}\right)$ is a third order polynomial expansion in the age of the oldest man and age of the oldest woman and all of their interactions. ${ }^{12}$ With the series expansion to control for age trends, the coefficient on the indicator for pension eligibility can be interpreted as the change in child labor associated with changing a person of gender $g$ from ineligible to pension eligible after controlling for the changes in child labor associated with the presence of generally older people.

\section{Results}

\subsection{Child labor}

\footnotetext{
${ }^{11}$ Consider three examples. First, pensioners are older than the aged who are not pension eligible. Thus, the pension indicator may capture that older people will have older grandchildren and great-grandchildren who are more likely to work and not attend school. Second, because the child and grandchildren of pensioners should be relatively older, there may be larger household sizes around pensioners. There are a number of ways in which household size may increase or decrease child labor supply. Third, surviving to pension age may indicate that elders (especially elder males) are in relatively rich households. Wealthier households may be less likely to have children work or may have greater employment opportunities open to children.

${ }^{12}$ Every regression in this paper has been re-estimated allowing the effects of pension income to vary by child gender. In every case, the data do not reject the hypothesis that the gender interactions are insignificant. Thus, gender interactions are not included in estimating (1) in the reported results.
} 
This study tests for liquidity constraints in child labor decisions by examining how child labor in black households in South Africa responds to the fully anticipated changes in non-labor income that comes from the OAP. Without liquidity constraints, increases in income may change savings, but child labor is determined by setting the return to not working equal to the opportunity cost of not-working. However, without savings, child labor supply in the first period depends on the household's marginal utility of consumption in the first period. Thus, the timing of household income can affect the labor supply of children in addition to savings and bequests. The test of the role of liquidity constraints in child labor decisions in this paper is to examine whether child labor supply changes when households move from anticipating the OAP income to actually being eligible to receive the income.

This study's empirical analysis is based on the June 1999 Survey of the Activities of Youth in South Africa (SAYP) described in detail in Appendix 1. The SAYP collects data on the activities of children over a 12-month reference period. The activities of children are grouped into household and market economic activities. Household economic activities include housekeeping and caretaking activities within the child's household or school. Market activities include running any kind of business, big or small, for the child him/herself; working unpaid in a family business; working in farming activities on the family plot, food garden, cattle post or kraal; catching or gathering any fish, prawns, shellfish, wild animals or any other food, for sale or for family consumption; doing any work for a wage, salary or any payment in kind; collecting wood for fuel or water; and begging for money or food in public. Total hours worked are the sum of hours in household and market economic activities. ${ }^{13}$

Table 1 contains the summary statistics for the children in black-headed households interviewed in phase 2 of the SAYP (see appendix 1). This study focuses on the 2,752 children

\footnotetext{
${ }^{13}$ Many studies of child labor ignore time in household work. However, this can produce very misleading results. For example, consider a household where a mother moves away from home to locations that better reward her skills. Children, then, pick up the household duties performed by the mother and exit the types of market work that they performed when their mother was present. This might look like a decline in child labor if household activities are ignored. However, if the child moves from attending to school and working 2 hours a week helping out on the farm to no school and 40 hours a week filling in for a parent, it would not be correct to claim that the child works less.
} 
ages 10-17 in columns 3 and 4 of table 1 that co-reside with a person between the ages of 50 and 75. Comparing children 10-17 that reside with an elder who is not pension eligible (column 3) to children that reside with a pension eligible person (column 4) suggests that pension eligibility is associated with a decline in total hours worked for children. The decline is larger in market work than in household work. Treating column 3 as the reference group, pension eligibility is associated with approximately a 10 percent decline in hours worked in market work.

Of course, this comparison in table 1 may confound age trends with the pension. Hence, age patterns in child labor are controlled for with the framework of (1). Table 2A begins by considering total hours worked in both market and household work. In column 1, after controlling for differences associated with the age of the oldest household members, hours worked declines by 2 hours when a female becomes pension eligible if there is no eligible male in the household and by 6 hours when a male is pension eligible if there is no eligible female. The combined effect of having both a male and a female pension eligible in the households is less than the sum of each individual's effect. Having both a co-resident male and female pensioner is associated with a decline in hours worked of approximately 5 hours. ${ }^{14}$

\section{Figure 1: Total Hours Worked and Pension Eligibility}

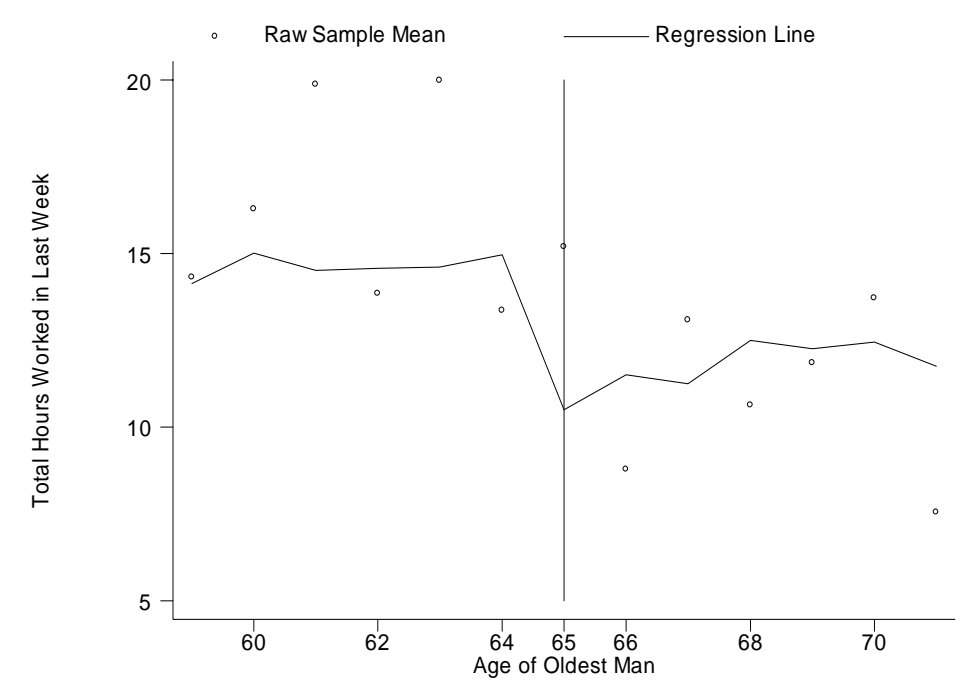

\footnotetext{
${ }^{14}$ Out of 2,752 children between ages of 10 and 17 that co-reside with a person age 50 or greater, only 172 report 0 hours of work. Hence, the left censoring of the hours worked distribution is not a substantive problem in table 3. However, column 6 contains Tobit results. They match the corresponding OLS results closely.
} 
Figure 1 presents the raw data and the results from column 1 of table $2 \mathrm{~A}$. The raw sample means illustrate the basic finding that child labor declines with pension eligibility. In households where the oldest man ranges between 59 and 64, average hours worked for children vary between 13.4 and 20 hours. However, between ages 66 and 71, average hours worked for children range between 7.5 and 13.7. ${ }^{15}$ The regression line in figure 1 is computed by calculating the mean for all of the regression variables conditional on the age of oldest man and plotting the regression line at each age of the oldest man with all of the corresponding means. ${ }^{16}$ The general age trend controlled for in (1) is evident in figure 1 as well. Both before and after age 65, child labor is increasing slightly in the age of the oldest man. The observed pension effect comes from the dramatic decrease in child labor that shifts the post 65 mean downward. An elasticity calculation helps in interpreting the result that hours worked declines by 6 hours per week with male pension eligibility. The mean hours worked for children that co-reside with an elder who is not pension eligible is 17 hours. If this is treated as a baseline for children that reside with a pension eligible male, the 6 fewer hours worked by a child who lives with a pension eligible male implies a 35 percent reduction in child labor. For a household with a pension eligible male receiving the pension, the benefit corresponds to a 122 percent increase in household income. ${ }^{17}$ The 35 percent reduction in child labor then implies a timing of income elasticity of child labor supply of approximately 0.3 .

\footnotetext{
${ }^{15}$ An obvious question in figure 1 is why child labor does not decline until after age 65 . One possibility is that there is significant delay in when the pension goes into effect. More likely, the picture reflects considerable measurement error in age. For example, the survey estimates the number of men age 65 to be 35 percent greater than the number of men age 64. Edmonds and others (2002) find even greater age-heaping in the South African census. One solution to this problem is to re-estimate the regressions in this paper, dropping all men age 65. Reproducing column 1 of table 2A for this nonrandom sub-sample suggests that male pension eligibility is associated with 6.5 fewer hours worked (t-statistic=3.04).

${ }^{16}$ Upon observing a child co-resident with a male pensioner, the probability that the child also co-resides with a pension eligible female is .57. Thus, the decline with pension eligibility evident in figure 1 corresponds to the 5 hours decline that accounts for the fact that men cohabite with women who may be pension eligible. If the sample is restricted to households where the only pension eligible individual is male, male pension eligibility is associated with 7.3 fewer hours worked per week (t-statistic=3.63).

${ }^{17}$ In order to predict income absent the pension for a household with a pension eligible man, the household's income category is regressed against the age of oldest man and woman polynomial for households with elder males that are not pension eligible. The results from this regression are used to predict household income (without the pension) for pension eligible males. Annual household income for a household with a pension eligible male would be between
} 
A way to interpret the magnitude of these findings is to estimate the total reduction in child labor affected amongst black South African households as a result of the eligibility of men for the social pension program. The SAYP estimates that there are approximately 531,771 black, pension eligible men in South Africa in 1999. On average, these men live with 1.1 children between the ages of 10 and 17 . If the average reduction associated with the pension eligibility of men is 6 hours per week, then over 180 million fewer hours were worked in 1999 as a result of the pension eligibility of men.

\subsection{Robustness}

The main identifying assumption in this approach is that the series expansion in elder ages controls for differences between households that vary in whether their elders are pensioners. That is, if a child in a pension eligible house is switched to an ineligible house, the labor supply for that pension eligible household child now in the pension ineligible house will be the same as a child living in a pension ineligible house. Specifically, for identifying the effect of male pension eligibility, the assumption is:

$$
E_{P E M=1}(H \mid A O F, A O M, P E F, P E M=0)=E_{P E M=0}(H \mid A O F, A O M, P E F, P E M=0) .
$$

The subscript on the expectations operator indicates whether the child is observed in a pension eligible house or not. The other conditioning variables then define the child labor supply that a child would experience absent the pension eligible male. The remainder of table 2A and table 2B examine the SAYP data for evidence against this identification assumption.

There are two testable implications of (2). First, (2) implies that the inclusion of other regression controls should not substantively alter estimates of the effect of pension eligibility on child labor. To explore this, columns $2-5$ of table 2A include various other controls in the basic regression (1). Column 2 of table 2A includes controls for each child's age. Column 3 adds province and urban fixed effects. Column 4 contains child age controls, province and urban

4201 and 6000 Rand per year without the pension. Treating the midpoint of this range as the average household income for a household with a male pensioner implies that average income for this group is 425 Rand per month. Thus, the pension of 520 Rand per month corresponds to a 122 percent increase in household income. 
fixed effects, and housing controls. ${ }^{18}$ Column 5 adds household composition controls to the covariates in column $4 .{ }^{19}$ All four control strategies lead to estimates of pension effects that cannot be distinguished statistically from the results in column 1 that just condition on the expansion in age of oldest man and woman. ${ }^{20}$ Thus, the data does not present evidence to reject the identification assumption in (2).

A second implication of (2) is that if artificial pension variables (e.g. assign pension eligibility to different ages) are created, there should not be any observed treatment effect. Table 2B contains these results. Column 1 pretends that pension eligibility occurs at age 55 for women and 60 for men. Column 2 pretends that pension eligibility occurs at age 65 for women, and 70 for men. Column 3 pretends that pension eligibility is at age 65 for women and 60 for men. In every case, there is no evidence of the large changes in child labor observed with the actual pension ages. Thus, the data do not reveal any evidence to suggest that the empirical method is providing false rejections of the hypothesis that child labor supply should not depend on the timing of income.

Throughout this study, the sample is restricted to households with persons age 50 to 75 . The purpose of this restriction is to make the households with and without pensioners relatively comparable so that the variation for which the age of oldest man / woman polynomial controls for minor. As a third robustness check, columns 4 and 5 of table 2B limit the source of variation used to identify the mean differences in child labor associated with pension eligibility. Column 4 includes dummy variables for the presence of a woman age 55 and man age 60 . Hence the

\footnotetext{
${ }^{18}$ The survey collects detailed data on house characteristics, but little other household asset information. Hence, housing characteristics are the best available way to control for differences in household wealth, although they may also depend on pension income (and could also depend on available child labor). Ex ante, one would expect conditioning on house characteristics to attenuate the observed pension effects, because pension income may lead to improvements in household characteristics. This may lead to less work for children.

${ }^{19}$ Household composition controls are a vector of dummies for the presence of a mother, a father, a grandparent, grandparents and parents, the number of household members $0-5,6-9,10-13,14-17,18-22,22-49,50-75$, and 76 plus.

${ }^{20}$ The remainder of this paper conditions on child age, gender, and province and urban fixed effects in addition to the polynomial in age of oldest man and age of oldest woman. Housing characteristics and household composition controls are not included because of concerns that they are jointly determined with child labor.
} 
interpretation of each of the pension indicators is the effect of having a pension eligible person relative to having a person of the same sex who is just below pension age. For this narrowed group, the data continue to suggest the table 2A results: 6 fewer hours of work associated with male eligibility and 2 fewer hours of work associated with female eligibility. Column 5 adds indicators for the presence of women above 65 and men above 70 . Thus, the pension indicators compare households where elders are within 5 years below pension eligibility to within 5 years above pension eligibility after controlling for age patterns. With this narrower source of variation, the magnitudes of pension effects change from table 2A, albeit not in a statistically significant way. Male pension eligibility is associated with 7 fewer hours of work and female pension eligibility is associated with 1 hour less of work.

In sum, all of the findings suggest that there are relatively large changes in the time a child spends working associated with the timing of pension income. The effects of pension income are largest when the pension recipient is a male. If the child labor supply decision is efficient in the Baland and Robinson (2000) sense that child labor supply reflects the balancing of returns to work against returns to school, whether or not the family has yet to receive the anticipated pension income should not affect the allocation of child time. Thus, the child labor results in this section are consistent with liquidity constraints leading to higher levels of child labor than market prices would affect.

\subsection{Schooling}

The test for liquidity constraints implies that anticipated income should not affect child labor nor should it affect schooling. Most studies of the link between schooling and child labor find a negative correlation between the two but are careful to point out that some levels and types of work are compatible with schooling. Thus, the observation in the previous section that pension eligibility (especially for males) is associated with declines in child labor does not necessarily imply that the data should reveal increases in schooling with pension eligibility. As a 
result, it is informative to examine the effect of pension income on schooling directly in a regression framework similar to (1).

There literature on liquidity constraints and schooling is a more developed on child labor supply. In the U.S. context, Card (2001) has argued that the general finding that estimates of the returns to schooling increase in an instrumental variable setting is consistent with liquidity constraints influencing college matriculation decisions although Carneiro and Heckman (2002) are skeptical of this interpretation. Kane (1994) and Ellwood and Kane (2000) find more direct empirical evidence of credit constraints in higher education decisions in the U.S., but Cameron and Heckman $(1998,2001)$ argue that their findings are more indicative of the effects of longterm family background factors. This argument may be relevant as well in the developing country evidence in Jacoby (1994) who examines liquidity constraints by comparing progress through schooling across households that differ in their asset holdings. A focus on household responses to pension eligibility avoids this difficulty, because the source of identifying variation does not depend on family background attributes or unobserved household characteristics.

These schooling results are in table 3 . In column 1 , the dependent variable is an indicator for whether a child currently attends school. Male pension eligibility is associated with increases in the probability that a child attends school. Curiously, declines in school attendance are observed when both male and female pensioners are present, but when all of the partials are added together in column 1 , the data cannot reject the hypothesis that there is no effect of pension eligibility on schooling when both men and women are present. Nevertheless, school attendance increases when men become pension eligible. Figure 2 mimics the format of figure 1, presenting the raw sample means (circles) and the regression results from table 3. Prior to pension ages, school attendance rates are below 91 percent. With male pension eligibility, attendance rates stay above 96 percent. Thus, the data suggest an effect of pension eligibility on schooling as would result if households are unable to incorporate anticipated income into decisions. 


\section{Figure 2: School Attendance and Pension Eligibility}

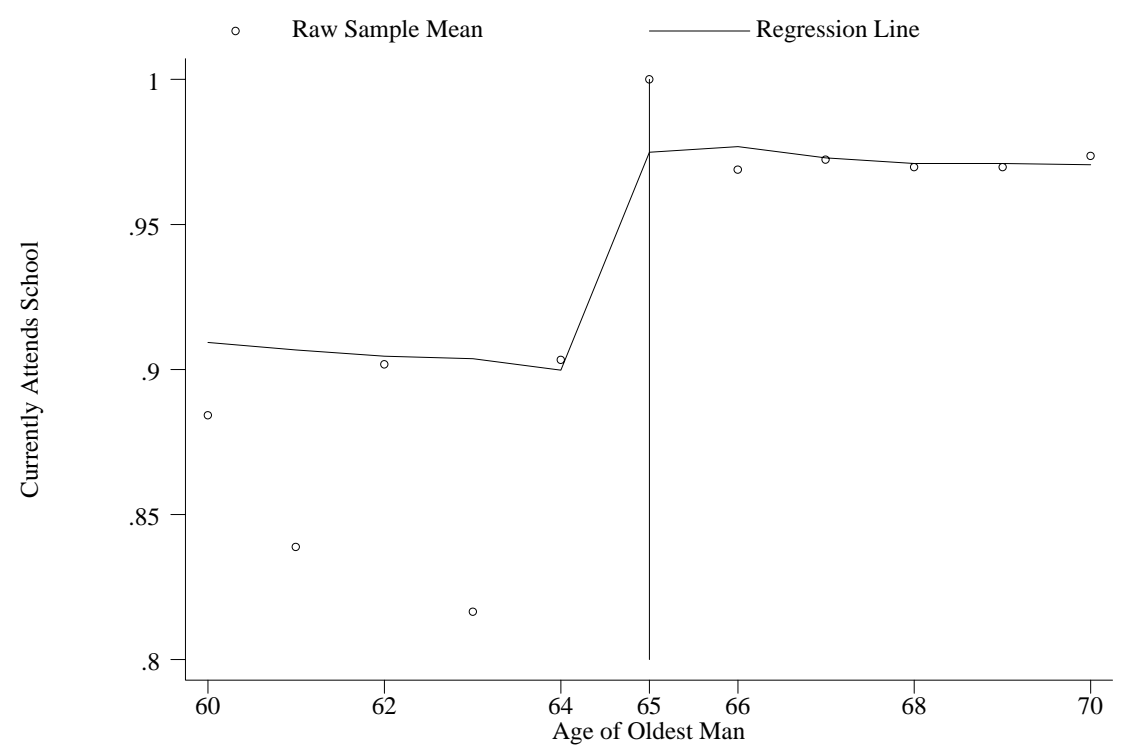

Attendance is a crude measure of schooling, because it does not capture time spent in schooling nor does it capture time spent learning school work. Both of these factors may be the more important mechanism through which child labor potentially trades off with schooling. While the dataset does not collect any information on time spent in school or on schoolwork, the questionnaire asks children that attend school if they have experienced financial problems with school in the last year and if work has forced them to miss school. Thus, columns 2 and 3 of table 3 are limited the sample that attends school. In column 2, the dependent variable indicates, conditional on currently attending school, whether a student is having problems with the cost of school. The incidence of schooling cost problems declines with both male and female pension eligibility, although the magnitude of the effect of male pension eligibility is almost three times that of female pension eligibility. Column 3 considers whether children that have missed school in the last 12 months have missed school for work. The probability that a child misses school for work declines with male pension eligibility.

Thus, the schooling and child labor data provide a consistent story. Receipt of anticipated large cash transfers is associated with increases in school attendance as well as primary school completion and declines in child labor. The pension eligibility of men is 
associated with over 180 million fewer hours worked by children in South Africa in 1999. The educational results are similarly significant. Male pension eligibility is associated with more than 23,000 children ages 10-17 attending school who otherwise would not (column 1 of table 3). If the decision to send a child to work reflects the relative return to child labor, then receiving additional cash income now (as opposed to receiving it in the near future) may affect savings decisions, but it should not affect schooling and the labor supply of children. Thus, these findings are consistent with substantive liquidity constraints.

\section{Identification and Interpretation}

\subsection{Differences associated with the gender of the pensioner}

The finding that pension income to a male is associated with greater reductions in child labor and increases in school attendance than is pension income to a female is surprising in the context of the existing literature on intrahousehold allocation with the Old Age Pension in South Africa. Duflo (2003) finds pension effects on child anthropometrics only when women receive pensions. Bertrand and others (2003) find greater adult labor supply effects when women receive pensions as well. These studies consider income effects and not liquidity constraints. If older women have longer life expectancies, the present value of the social pension is larger for women than for men, and therefore there should be larger income effects when women become eligible for the social pension. With regards to liquidity constraints, if both men and women face liquidity constraints, the magnitude of the importance to the household of actually receiving the pension may dwarf the differences in present value of the male and female pensions. This argument suggests that male and female pension eligibility should be associated with similar effects on child labor. In many specifications, the data do not reject the hypothesis that male and female pension eligibility affects the same reduction in child labor even though the magnitude of the male coefficients is larger and statistically different from zero. However, it is worth considering why the data might suggest large effects for male pension eligibility so uniformly. 
One possible explanation that is not correct is that male pension eligibility captures nonlinearity in income. Roughly half of all pension eligible men also live with a pension eligible female, but the effect of adding a pension eligible male to a household with a pension eligible female is the coefficient on male pension eligibility plus the interaction term which generally attenuates the effect of male pension eligibility to be of the same magnitude as female eligibility (in table 2A for example). Thus, when men and women co-reside, the timing effects for men and women are similar. The large changes in child labor and schooling are observed when men do not co-reside with pension eligible women.

One possible explanation for this is that men are more liquidity constrained than are women and that the presence of a female pensioner relaxes the liquidity constraint for men. Men might be more liquidity constrained for several reasons. First, it is possible that because women have a higher life expectancy, they face a weaker liquidity constraint than men. Higher mortality risk makes future income more uncertain for men. Second, if women have greater savings rates then men, then men are more apt to be liquidity constrained. There might be gender differences in savings or access to formal credit, because of some aspect of the male personality or because women are more active in formal and informal lending groups in South Africa. For example, informal savings groups called "Stockvels" are ubiquitous in South Africa, and they are typically all female.

Another possibility is that the difference between men and women may reflect some type of selection process for men working either through living arrangements or mortality. For example, assume the distributions of tastes for education (or distaste for child labor) in the male and female populations of South Africa are identical and that the distribution of liquidity constraints in male and female populations are identical. Further, suppose that surviving elderly women typically cohabitate with their extended family but that men do not, and that the men that cohabitate with extended family are those with strong tastes for schooling or those that are particularly liquidity constrained. Then, the pension eligibility of men will be associated with 
larger changes in child labor and schooling than that of women, because of this selection into what men live with children. More generally, men and women can be equally liquidity constrained, but any self-selection mechanisms that leads the sample of cohabitant men to be either more altruistic or more liquidity constrained could cause changes in child labor and schooling to be larger for men.

In addition, it is not difficult to reconcile the finding of larger reductions in child labor with male pension eligibility with other studies of the OAP in a very simple model of intrahousehold allocation where men and women have different spheres of control. Becker (1973) and Lundberg and Pollak (1993) develop models of the household where men and women specialize into separate spheres of control within the household. While a person's sphere of influence in the household may depend in part on the resources at that person's command (e.g. Lundberg and others 1997; Thomas and others 1999), it is conceivable that the effect of cash transfers on the person's spheres of influence may be of second order relative to the ability of a person to affect behavior within their existing sphere. In Becker's model, women specialize within the household and men outside of the household. In this world, then, cash transfers to women might have greater effects on within household decisions about children and cash transfers to men might have larger effects on how children interact with the outside world and in traditionally male dominated spheres. Moreover, if household production activities (which may fall in female spheres of influence) are less income elastic, then the data should reveal larger declines in child labor with male pension eligibility. This can be examined by looking at child labor supply in different types of work.

In fact, the data suggests the largest reductions in child labor are in market work (work for wages, work for a household business, work on a farm). Table 4 breaks hours worked into hours in household activities and hours in market work. Girls work more in the household and less in market work, although the difference in market work hours is not statistically significant. In columns 1 and 2 (column 2 contains Tobit results), the data do not reject the hypothesis that 
neither the pension eligibility of men or women has any effect on child labor supply to household activities. Most of the reduction in hours worked with pension eligibility appears in market work (columns 3 and 4). In fact, out of the 6 hours less work per week experienced by children living with a pension eligible male, 5 of those hours appear to be in market work. Thus, the fact that the statistically significant results in the data reject the model without liquidity constraints when men receive pension income appears easily reconcilable with an extension of the basic model of intrahousehold decision-making.

\subsection{Alternatives to the liquidity constraint interpretation}

This study has interpreted the finding that child labor supply and schooling are responsive to the timing of income as evidence of liquidity constraints affecting these time allocation decisions. There are, however, alternative explanations for why the timing of income affects child labor supply and schooling. First, as noted by Beegle, Dehejia, and Gatti (2003) in their discussion of an early draft of the present study, households may be myopic and not anticipate future income. If this were true, then the results of this study would reveal an income effect, not a liquidity constraint. Given the strong evidence that households in developing countries can smooth consumption over predictable seasonal variation in income in Paxson (1993) and Jacoby and Skofias (1998), it seems reasonable to assume that households are not myopic in their decisions with respect to a doubling of income like the Old Age Pension. Moreover, if households were myopic, it becomes difficult to understand the evidence that suggests schooling decisions are sensitive to anticipated returns to education such as Foster and Rosenzweig (1996).

Second, peer pressure to share income among family members may increase when pension cash is on-hand. In the absence of liquidity constraints, actual pension receipt should have little impact on the well-being of the elderly. It seems plausible to assume that peer pressure to share income and wealth is driven by an individual's relative living standards rather 
than her cash on hand. Under this assumption, then, the pressure to share income does not depend on the timing of income except under liquidity constraints.

Third, in the context of consumption responses to anticipatable social security tax changes in the U.S., Parker (1999) argues that a boundedly rational household may allow spending decisions to track income provided that this strategy does not make the household too much worse off than the fully rational strategy. This behavior occurs, because it is costly for the individual to re-optimize her consumption plan with each change in income. Given the magnitude of the cash transfer stemming from the old-age pension, it is hard to imagine that this nearly rational rule of tracking child labor and schooling to income would not make the household much worse off.

Two pieces of evidence suggest a scope for liquidity constraints to be the correct interpretation of the findings in this study. First, men who co-reside with pension eligible women are less likely to be liquidity constrained because of the income brought in by the woman' pension. In fact, when a man co-resides with a pension eligible woman, his pension eligibility yields about the same changes in child labor supply and schooling that does female eligibility (relatively small in magnitude and statistically insignificant, see table 2A). Thus, the observed pension effects occur when only the female pensioner's income is not present. Second, less educated elders may be more likely to be liquidity constrained. If liquidity constraints are in play, the data should suggest larger pension effects on child labor supply and schooling in households where the elders are relatively less educated (assuming that myopia, peer influence, and the propensity to exhibit boundedly rational behaviors do not vary with education). In the context of black South Africa, even the wealthiest 10 percent of the population are still very poor and maybe liquidity constrained. Thus, a failure to find variation with elder education does not necessarily reject liquidity constraints as an explanation.

To explore this, the specification of equation (1) is modified to include interactions with the elder's education, EOM and EOF for eldest male and female respectively: 


$$
\begin{aligned}
H_{i j}= & \beta_{0}+\beta_{1} P E F_{i}+\beta_{2} P E M_{i}+\beta_{3} P_{E F}^{*} P E M_{i}+\beta_{4} P E F_{i}^{*} E O F_{i}+ \\
& \beta_{5} P E M_{i} * E O M_{i}+\beta_{6} P E F_{i}^{*} P E M_{i} * E O F_{i}+\beta_{7} P E F_{i} * P E M_{i} * E O M_{i} \\
& +\alpha_{1} E O F_{i}+\alpha_{1} E O M_{i}+\pi\left(A O M_{i}, A O F_{i}\right)+\varepsilon_{i j}
\end{aligned}
$$

Thus, the interpretation of $\beta_{2}$ is now the change in hours worked associated with the pension eligibility of a male with no education in a household without a pension eligible female. $\beta_{5}$ is the incremental change in hours worked associated with the pension eligibility of a male for each additional year of education of that male in a household without a pension eligible female. The results from this specification are in Table 5.

Each column in Table 5 includes a different dependent variable. In column 1, the dependent variable is total hours worked in the last week. Column 2 considers results for hours in household work, column 3 refers to hours in market work, and column 4 contains marginal effects for the probit regression where the dependent variable is an indicator for whether the child reports attending school. Each regression mimics the specification of column 3 in Table 2 A. $^{21}$

Child labor declines are decreasing in the education of male pensioners. Consider the case of a male elder who becomes pension eligible and does not reside with an eligible female. The estimated decline in hours worked associated with pension eligibility is 40 percent higher when the elder male has no education (compare Column 1 of Table 5 to Column 3 of Table 2A). Each additional year of education reduces the estimated decline in hours work with the pension eligibility of males by 8 percent so that the estimated decline in total hours worked associated with the pension eligibility of males is zero for pensioners who have completed high school. The data do not suggest a link between the education of elders and the association between pension eligibility and school attendance, but this may just be because the only households in which there was any margin to move school attendance substantially were households with low education. An alternative specification would bifurcate the sample based on the education of the elders. If

\footnotetext{
${ }^{21}$ The dataset is missing education of elders for 146 children, and they are omitted from the analysis.
} 
the sample is restricted to pensioners without completed primary school, the results correspond to what would be expected from Table 5: less educated elders experience larger declines in child labor with pension eligibility. Thus, the declines in child labor are largest in households that are most apt to be liquidity constrained.

\subsection{Additional Identification Issues}

The above results are based on comparing households that currently receive the pension to households that will receive the pension in the near future after controlling for general patterns in child labor and schooling associated with the age of the oldest man and woman in the household. This section highlights issues of lead and lags in program response, measurement error in age, endogenous household composition, retirement absent the pension, price effects of the means-test, and cohort effects that should be discussed in the context of this study.

First, households may respond to the pension either before or after actual eligibility even in the presence of liquidity constraints. For example, a household may keep children in school in anticipation of the pension income. This is particularly likely to be a problem if there are large "diploma” effects in the rewards to education. Consider a household with a seven year old girl. She can go to school now or she can work. If a parent knows that in two years time, the girl will be needed to work and hence she will not complete primary school, a parent may choose to keep the child at home now (if the large payoff to schooling is past the point of the girls expected termination of schooling). However, if the household anticipates receipt of the pension income in two years, then it knows that the girl can continue schooling in two years. Hence, the household continues schooling today. With the approach of comparing households with a pensioner to households without a pensioner but near to a pensioner, this "lag or lead" problem will attenuate any observed effects of the timing of income.

Second, measurement error in age in the survey maybe a problem, because black South Africans have only recently begun to systematically register births. This has created an administrative problem in implementing the South African OAP, because elder blacks without an 
official documentation of their births have incentives to try and persuade government officials that they are of pension eligible age. It is conceivable that survey respondents may believe that inflating ages in completing the data used below may help them receive pension income.

Moreover, there may be targeting errors in the pension program such that some persons receive the pension other than at ages of eligibility. Hence, there are likely to be several households defined as pension eligible that are not eligible and some households classified as ineligible that receive the pension. This would attenuate the observed study's findings. One option would be to omit pensioners at the ages of pension eligibility from the analysis. As evident in Figure 1 and discussed in footnote 15, estimates of the effects of male pension eligibility on child labor supply increase if the pension age is omitted from the analysis.

Third, some households respond to the pension by re-arranging (Edmonds and others 2003). Thus, the observed effects of the pension on child labor may actually just reflect changes in household composition rather than a change in child labor supply. In Edmonds and others (2003) male pension eligibility is associated with a 7 percent increase in children in the age group studied here. Under the hypothesis that children do not change their labor supply with the pension but rather that children who do not work move in, the 7 percent increase in these nonworking children implies that male pension eligibility would be associated with 1.2 fewer hours of child labor. Hence, the results of this study are too large to be explained purely by children who do not work moving in. In fact, there would need to be a 33 percent increase in children (none of whom work) to generate the observed reductions in child labor with the pension. Moreover, Column 5 of table 2A includes controls for both the presence of family (mother, father, grandparents) and the number of household members in various demographic groups. Estimates of the observed effects on child labor of male pension eligibility are even larger with these household composition controls. This issue is discussed in greater detail in Appendix 2.

Fourth, retirement, absent the pension program, may complicate the interpretation of this study's findings. If women stop working at 60 and men at 65 without the pension program, the 
effect of retirement is intertwined with my estimates of the effect of the pension program. Note: the problem is not that the pension may induce individuals to retire and thereby influence child labor and schooling. If liquidity constraints prevent individuals from retiring and this thereby influences child labor supply, the results of this paper capture an indirect effect of the timing of income on child labor. Rather, a problem arises if retirement absent the pension occurs at ages 60 for women and 65 for men.

This is impossible to test in the data, but there are several reasons why this problem may not substantively alter the discussion. First, most black South Africans are not engaged in formal employment that would have a fixed retirement age (Edmonds, Mammen, and Miller 2003). Second, most black South Africans are sufficiently poor that they do not have the luxury of terminating employment at a specified age (in the absence of the pension). Typically, poor health and other problems associated with aging force the elderly out of employment. Third, in a more general model of child labor than in section 2 where the value of child time inside the household is affected by the activities of other members, retirement could affect child labor supply within the household even when child labor decisions are efficient. However, the largest effects observed above are in market work where the value of child time is more plausibly exogenous. Hence, retirement is unlikely to be an important omitted variable in the results above.

Fifth, the means-test in the pension benefit formula could create incentives to retire at age 60 for women and age 65 for men. If implemented in practice, the means-test could create a price effect that would induce retirement. Child labor could then be affected by this price induced retirement as with retirement absent the pension. As discussed in section 3.1, the data do not suggest much scope for the means-test to be applied to black South Africans (9 percent of control households report household incomes at the level where individual incomes could be taxed), nor is there any evidence that the means test binds (96 percent of pension recipients reports incomes at or above the maximum benefit). Moreover, the discussion in section 5.2 
suggests that the pension eligibility effects are largest amongst the least educated households who are least apt to be affected by the means-test. Thus, the data do not suggest that means-test induced retirement is likely to be a significant source of bias.

Sixth, age targeted government programs or interventions towards could be associated with pension eligibility, because older children are more apt to have an older grandparent who is thereby more apt to be pension eligible. This sort of cohort effect is unlikely to be a problem in estimation for several reasons. First, child age and elder age are not perfectly correlated. The data contain both 12 year olds that live with pensioners and 12 year olds that do not. Thus, the inclusion of the polynomial in child age should control for age-specific factors. When table 2A controls for differences in child age (column 2), estimates of the effects of pension eligibility do not vary outside of the hundredths position from the estimates without age controls (column 1). Second, gross primary and secondary school enrollment rates have been increasing in South Africa throughout the 1990s (World Bank 2001). If older children are more likely to be in pension households and less likely to have attended schooling, the bias from these omitted education trends would be away from finding an effect of pension income on schooling. Third, omitted anti-child labor policies are unlikely to be behind this paper's findings. International legislation is unlikely to differentially effect the 10-17 year olds considered in this paper in ways that the pension indicators will capture. South Africa has been a signatory on the UN Convention on the Rights of the child since 1989 and just signed the UN Convention on the Elimination of the Worst Forms of Child Labor in 1999. Domestic legislation has been minimal and likely to be more strongly associated with younger children. The Basic Conditions Employment Act of 1997 prohibits the employment of children younger than 15 and regulates the employment of children over 15 . Thus, if this legislation has any effect, it would be to decrease the activities of younger children (thus biasing away from finding pension effects). ${ }^{22}$

\footnotetext{
${ }^{22}$ If the Act has been effective, there should be discontinuous changes in child labor supply or in the probability that a child works for pay at age 15. However the SAYP does not reject the hypothesis that the labor supply of 15 year olds is the same as that of 14 and 16 year olds.
} 
The 1996 constitution assigns every child a right to "be protected from exploitative labor practices ...", but there do appear to be any concrete policies that have followed from this other than the Basic Conditions Employment Act.

\section{Conclusion}

This study finds that anticipated large cash transfer to the elderly in South Africa appear to be associated with increases in schooling and large declines in child labor. The average South African child living with an elder that is not yet pension eligible spends 17 hours a week working. In the data, pension income to an elder male is associated with 6 hours less work. Most of this decline in child labor is in market work which includes work in agriculture, work for pay, or work in a household business. Schooling attendance in South Africa is relatively high, so the effects of pension income on schooling are necessarily much smaller. 96 percent of children that co-reside with an elder who is not pension eligible attend school. The data suggest that pension income paid to an elder male is associated with school attendance rates that are close to 100 percent. These findings are robust to several specification checks, and they imply a large overall effect of the pension program. For example, the results for male pension eligibility imply that 23,000 children are attending school who would otherwise not and a total of over 180 million fewer hours were worked in a 1999.

The main focus of this study has been to test whether child labor supply is influenced by liquidity constraints. Baland and Robinson (2000) show that if a family faces liquidity constraints, then child labor is inefficiently high (from the family's perspective), because child labor supply is determined by the marginal utility of consumption rather than the return to educational investments. This study tests the efficiency of child labor decisions by examining how black households in South Africa respond to the fully anticipated, permanent changes in non-labor income that comes from the OAP. If households are saving, the increased income may affect savings, but child labor decisions should be unaffected if they are already at an efficient

level (where the private return to education equals its private opportunity cost). However, the 
findings of this paper suggest that some households with working children would rather their children not work, but because of some sort of market imperfection that creates liquidity constraints, households are forced to send their children to work. The results of this paper are consistent with a story where an inability to borrow against a child's future return to education forces households to under-invest in education. Receiving large cash transfers weaken this cash constraint, and hence children work less and attend school more.

As with much of the literature on the South African pension program, the child labor data reveal different effects when men receive pensions than when women receive pensions. In particular, the effects of income on child labor and schooling are larger and have greater statistical significance when men receive the pension than when women receive the pension. It might be possible to interpret this as a rejection of the unitary household model, but the puzzle is why pension effects appear larger for men. Most of the intrahousehold literature finds larger benefits to children when women receive pension income. Men and women may differ in the extent to which they are liquidity constrained, or they may have different spheres of control within the household. Thus, income to women affects food and nutrition decisions whereas income to men affects the labor supply of children. Of course, although the magnitudes and statistical significance of the effects of income to men are larger, the data do not reject in every specification the hypothesis that income to men and women have equal effects on child labor and in schooling. Thus, the data do not support a strong intra-household interpretation of these results.

The policy implications of the finding that child labor is affected by the timing of income are substantial. A great deal of the literature on the determinants of child labor, going back as far as Marx, argues that parents send their children to work, because the return to working is greater than the return to not-working. This view then suggests that, if ending child labor is a policy priority, countries should focus on interventions directly related to child labor. For example, countries should use coercion to forcibly lower the return to child labor or increase returns to 
schooling. However, the results of this study suggest that, for some households, child labor stems more from market imperfections than from high returns to child labor or low returns to education. Hence, in these households liquidity constraints are affecting higher child labor supply, attacking child labor may best be accomplished by attacking poverty, developing markets, and building financial intermediaries. With substantive liquidity constraints, actions design to prohibit child labor directly (such as trade sanctions) may impose costs on the poorest parents rather than the most callous and could, in the end, serve to worsen child labor (Ranjan 2001). 


\section{Appendix 1: The Survey of the Activities of Young People, 1999}

The 1999 Survey of the Activities of Young People or SAYP (conducted by Statistics South Africa with the help of the International Labor Organization) is the first nationally representative survey in South Africa to collect detailed data about the allocation of child time. The survey also collects basic information about all of the members of a child's household including age eligibility and participation in the OAP.

The SAYP was conducted in two phases (Statistics South Africa 2000). The first phase employed a brief questionnaire designed to identify whether or not a household had children and, if so, if any children participated in any economic activities. In the SAYP, a household consists of a single person or a group of people who live together for at least four nights a week, who eat together, and who share resources. A household may occupy more than one structure. People that occupy the same dwelling unit but do not share food or other essentials are regarded as separate households. A domestic worker living in separate domestic workers quarters or who is paid a cash wage by the main household (even if she or he has most of her or his meals with the household) is regarded as a separate household. In this way, this study misses domestic workers that live within their employer's household in separate quarters.

Of the 10,480 sampled black households with children in phase 1, 74 percent had at least one child participating in an economic activity. In phase 2, a sample was drawn out of the subpopulation with any working children. The definition of working for this re-sampling was broad: it included both household duties as well as work outside of the household. In this second phase, detailed questions about the allocation of child time were administered. Both phase 1 and phase 2 are studied in the empirical work in the text, but the detailed schooling and child labor data come from the phase 2 sample. Hence, these results are only representative to the population of households where at least one child works an hour or more in household or market production.

The aim of this paper to use the data on child labor in households without pensioners but with someone over 50 to learn about what the labor supply of children that co-reside with pensioners would be absent the pension, after controlling for general age trends. If the effect of the pension income is to move households from having children working to no children working, then the group in the data that are both pension eligible and qualify for the second round of the SAYP might be special and incomparable to the group of households without a pensioner but with a child labor. To evaluate this problem, an indicator for whether a household is selected into phase 2 is regressed on pension eligibility. Having a co-resident female pensioner decreases the probability of being selected by 1.5 percentage points and having a co-resident male pensioner increases the probability of being selected by less than a tenth of a percent (for a baseline, 22 percent of black phase 1 households with a person over the age of 50 are reinterviewed in the second phase). Both coefficients have t-statistics that are less than 1 . This finding that sample selection is not associated with pension eligibility is consistent with the results in the text: the reductions in child labor are in the hours of work and not in participation rates.

This study focuses on children ages 10-17 in households with a black head. All of these children were born before the end of apartheid. Hence, their parents are unlikely to have anticipated pension income at the time of conception. Table A1 presents summary statistics for households with black household heads in the full SAYP sample and for the various restricted 
samples that are used in this study. All descriptive statistics in table A1, including the phase 2 sample, are weighted to be nationally representative.

Households in the Phase 1 and Phase 2 samples look similar. This reflects the fact that three-fourths of the phase 1 sample (column 1 ) is eligible for phase 2 . Hence, the phase 2 sample in column 2 is a random sample of most of the households in column 1.

Table A1 also illustrates that there is ample scope for the direct, within household sharing of income between the elderly and younger generations. Households with a pensioner and a working child 10-17 (column 5) have on average 1.9 children between the ages of 10 and 17 . In the full, phase 1 sample (column 1), 26 percent of black households with children 10-17 also have a resident, pension eligible person and 26 percent report receiving pension income. Thus a substantial portion of households with children are directly affected by the OAP.

Four interesting characteristics about pension income, relevant to this study, are in table A1. First, 79 percent of households with a pension eligible person report receiving pension income. Pension take-up appears to not be universal (Case and Deaton 1998 find this as well), but a large portion of the eligible population receives it. Second, there is some leakage in the pension program (this is known to occur) or measurement error in reported ages. 13 percent of households without a person that is pension eligible report receiving pension income. In column 2, 7 percent of households without a person age 50 to 75 report pension incomes, but these households can include pension eligible persons above the age of 75 . Third, the average number of pensioners per household is 1.2. Thus, some households may receive pension income from multiple individuals. Fourth, co-residency of children with pension eligible women is more common than is co-residency of children with pension eligible men. However, the difference in co-residency rates is approximately the same as the presence of pension eligible men and women in the general population (author's calculation from the full SAYP sample).

The raw data are also consistent with an increase in household income associated with the pension. In columns 4 and 5 of table A1, the sample is restricted to households with a person between the age of 50 and 75 . When the household elder is pension eligible, the probability that the household reports receiving pension income increases by 600 percent. Moreover, in this same sub-sample, the probability that a household reports an income above the pension amount of 520 Rands per month rises by 12 percentage points if at least one of the persons above 50 is pension eligible (t-statistic 8.167). Hence, there is evidence within the SAYP that pension eligibility is associated with increased income.

\section{Appendix 2: Household Composition, Child Labor, and the Old Age Pension (OAP)}

\section{A2.0 Overview}

Pension income may induce children or other household members to move. This observation has two possible implications for this study. First, part of the mechanism through which pension income affects child labor is via changes in household composition. This relates to the question of whether the observed effects are direct or indirect effects of liquidity constraints on child labor. Second, if household composition shifts systematically with pension eligibility, the age of oldest male and female polynomial cannot fully capture all of the differences between child labor in pension eligible and ineligible households in the absence of pension income. Thus, it is impossible to construct the counterfactual of what child labor would look like in the absence of pension income in pension eligible households. 
The data permit four ways to assess the importance of shifts in household composition in this paper's findings. First, is there any evidence of changes in household composition with pension eligibility? Edmonds and others (2003) look in the South African census and find relatively small changes in household composition. Based on their findings, it is unlikely that household composition shifts can generate all of the results in the text, but this appendix considers evidence of movements in household composition in the SAYP. Second, the SAYP collects migration information on children. Restricting the sample to children who have not moved recently only addresses one type of change in household composition with pension income, but this is the only movement information in the dataset. Third, after partialing out all of the differences in child labor association with household composition, is there any evidence of a link between child labor and pension eligibility. This approach limits the variation with which to identify pension income effects on child labor if there is any association between pension income and household composition. Fourth, is there any observed pension effect after controlling for household composition rather than redefining the dependent variable as household composition adjusted child labor. This has already been discussed in the text and is not further explored here. None of these approaches suggest large changes in the basic findings of this paper.

\section{A2.1 Co-residency of pensioners with children}

In phase 1 of the SAYP data, there are 4,372 households with a person between the age of 50 and 75 . For these households, the number of children who appear in the household (children age 10 to 17) is regressed against pension eligibility with and without controlling for the age of oldest man and woman. These results are in appendix table A2. Without controlling for general age trends, there is a positive association between a single pension eligible female or a single pension eligible male and the residency of children although the coefficient on male pension eligibility is not statistically significant. The magnitude of the association between single male pension eligibility and number of children increases upon controlling for general age trends, but the data do not reject the hypothesis that there is no association between pension eligibility and the number of co-resident children. In the phase 2 sample used throughout the paper, there is no statistically significant evidence of any association between pension eligibility and the co-residency of children. Moreover, the estimated magnitudes of the association between children and pension eligibility are very close to zero. This difference between phase 1 and phase 2 findings may be attributable to the sample selection issues discussed in the previous appendix.

\section{A2.2 Child migration and pension eligibility}

While the data used in most of the paper do not suggest substantive increases in the presence of children around the elderly with the pension program, there could be important marginal changes that provide much of the variation used in earlier sections. The only information in the SAYP about changes in household composition comes from asking children 10-17 if they have moved in the last two years. Appendix table A3 replicates most of the key regressions of the paper, restricting the sample to children who have not moved (this obviously does not control for movement by other household members). Only 162 children between 10 and 17 that co-reside with a person above the age of 50 have moved in the last two years. This group does not appear to be particularly important in the previous sections' findings, because all of the results in the sample restricted to children that do not move are well within standard confidence intervals of the full sample results. 


\section{A2.3 Controlling for household composition effects}

Another approach to the household composition problem is to first control for all of the variation in child labor associated with variation in household composition and then to relate the remaining variation in child labor to pension eligibility. This can be accomplished in two steps. First, regress labor supply of child $i$ in household $j$ on various measures of household composition:

$$
H_{i j}=\alpha_{0}+\alpha_{1} G_{j}+\alpha_{1} P_{i}+u_{i j}
$$

where $G$ is a vector of counts of the number of co-resident persons in ages $0-5,6-9,10-13,14-$ $17,18-22,22-49,50-75$, and 76 plus in child $i$ 's household $j$ and $P$ is a vector of indicators for the presence of child $i$ 's mother, father, grandmother, grandfather, and both grandparents and parents. Second, regress the residuals from (3) on the pension indicators and age of oldest man and woman series as in (1):

$$
u_{i j}=\beta_{0}+\beta_{1} P E F_{i}+\beta_{2} P E M_{i}+\beta_{3} P E F_{i} * P E M_{i}+\pi\left(A O M_{i}, A O F_{i}\right)+\varepsilon_{i j} .
$$

The advantage of this approach is that it conditions out all of the differences in child labor associated with the household's population. It comes with three costs. First, this decomposability property is only a property of OLS, so the schooling results need to be reestimated with linear probability models. Second, to the extent that there is any variation in household composition associated with pension income, the household composition controls capture these pension effects, limiting the variation available to identify pension effects in (5). Third, the dependent variable in these regressions is different from the regressions in the text. Hence, the comparability of this exercise to the results above is questionable.

The results from this exercise are in appendix table A4. For each pension indicator (male, female, pem*pef), the percentage change in the regression coefficient is reported after controlling for household composition differences. The estimates of $\beta_{i}(\mathrm{i}=1,2,3)$ in the basic model (1) are treated as baselines for the purpose of calculating percentage changes. The p-value for the null hypothesis that there is no change in $\beta_{i}$ between models (1) and (5) is also reported. Finally, the p-value for the null hypothesis that $\beta_{i}$ is zero in (5) is reported.

A few results stand out in appendix table A4. First, the data never reject the hypothesis that there is no change in estimates of $\beta_{i}$ between models (1) and (5). Thus, as in the previous appendix tables, there is no statistically significant evidence of biased inference from household composition shifts. Second, after conditioning out household composition variation, the hypothesis that the effects of pensions for women or for having both women and men are actually zero cannot be rejected. However, the key effects for men persist even after partialing out household composition. There are statistically significant declines in total hours worked that appear to primarily be in hours in market work. Moreover, there is a statistically significant increase in schooling for children between the ages of 10 and 17. In missing school for work, there are large changes in estimates of the effects of pension eligibility, but these coefficients are highly variable to begin with, so it is not clear how to interpret these changes. Overall, the data do not reveal any evidence to suggest that shifts in household composition drive the results in the text. 


\section{Works Cited}

Alderman, H. (1999): "Safety Nets and Income Transfers in South Africa." World Bank Africa Region Discussion Paper 19335. February.

Baland, J. M. and J. Robinson (2000): “Is Child Labor Inefficient,” Journal of Political Economy, August, 108(4), 663-79.

Basu, K. and P. H. Van (1998): “The Economics of Child Labor,” American Economic Review, 88(3), 412-427.

Beegle, K., R. Dehejia, and R. Gatti (2003): "Child Labor Supply and Crop Shocks: Does Access to Credit Matter," World Bank Working Paper 3075, May.

Becker, G. (1965): "A Theory of the Allocation of Time," Economic Journal, 75, September, 493-517.

Becker, G. (1973): "A Theory of Marriage." Journal of Political Economy. 81: 813-846.

Becker, G. (1975): "Human Capital and the personal distribution of income: an analytic approach," in Human Capital. Chicago: University of Chicago Press.

Becker, Gary and Nigel Tomes (1976): "Child Endowments and the Quality and Quantity of Children," Journal of Political Economy, 87(4) pt.2, S143-S162.

Ben-Porath, Y. (1967): "The Production of Human Capital and the Life Cycle of Earnings," Journal of Political Economy, 75(4), 352-65.

Bertrand, M., S. Mullainathan, and D. Miller (2003): "Public Policy and Extended Families: Evidence from South Africa.” World Bank Economic Review 17(1), 27-50.

Bommier, A. and P. Dubois (2003): "Rotten Parents and Child Labor," Journal of Political Economy, forthcoming.

Brown, D.K., A. Deardorff, and R. Stern (2001): “Child Labor: Theory, Evidence, and Policy,” Research Seminar in International Economics Discussion Paper \# 474, University of Michigan.

Browning, M. and A. Lusardi (1996): "Household Saving: Micro Theories and Macro Facts," Journal of Economic Literature, 34(4), December, 1797-855.

Cameron, S. and Heckman, J. (1998): "Life cycle schooling and dynamic selection bias: models and evidence for five cohorts of American males," Journal of Political Economy, 106(2), 262-333.

Cameron, S. and Heckman, J. (2001): "The dynamics of educational attainment for black, Hispanic, and white males," Journal of Political Economy, 109, 455-99.

Card, D. (2001): "Estimating the return to schooling: progress on some persistent econometric problems," Econometrica, 69(5), 1127-60.

Carneiro, P. and J. Heckman (2002): "The Evidence on Credit Constraints in Post-Secondary Schooling," Economic Journal, 112, 705-734.

Case, A. (2001): "Does Money Protect Health Status? Evidence from South African Pensions.” Princeton Manuscript.

Case, A. and A. Deaton (1998): “Large Cash Transfers to the Elderly in South Africa.” Economic Journal, 108(September): 1330-1361.

Dehejia, R. and Gatti, R. (2002): "Child Labor: The Role of Income Variability and Access to Credit in a Cross Section of Countries.” NBER Working Paper \#9019, June. 
Duflo, E. (2000): “Child Health and Household Resources: Evidence from the South African Old-Age Pension Program” American Economic Review: Papers and Proceedings, May 2000.

Duflo, E. (2003): "Grandmothers and Granddaughters: The Effects of Old Age Pension on Child Health in South Africa," World Bank Economic Review, 17(1), 1-25.

Edmonds, E. (2003): "Does Child Labor Decline with Improving Economic Status?" Journal of Human Resources, forthcoming.

Edmonds, E, K. Mammen, and D. L. Miller (2003): "Rearranging the Family? Income Support and Elderly Living Arrangements in a Low-Income Country” Dartmouth College Manuscript.

Ellwood, D. and Kane, T. (2000): "Who is getting a college education?: Family background and the growing gaps in enrolment," in (S. Danziger and J. Waldfogell, eds.), Securing the Future, New York: Russell Sage.

Foster, A. and Rosenzweig, M. (1996): "Technical Change and Human Capital Returns and Investments: Evidence from the Green Revolution," American Economic Review, 86, 4, September, 931-953.

Frankenberg, E., J. Smith, and D. Thomas (2003): "Economic Shocks, Wealth, and Welfare," Journal of Human Resources 38(2), 280-321.

Guarcello, L., F. Mealli, and F. Rosati (2003): "Household Vulnerability and Child Labor: The Effect of Shocks, Credit Rationing, and Insurance," Understanding Children's Work Working Paper, July.

Jacoby, H. G. (1994): "Borrowing Constraints and Progress through School: Evidence from Peru,” Review of Economics and Statistics, 151-160.

Jacoby, H. G. and E. Skoufias (1997): "Risk, Financial Markets, and Human Capital in a Developing Country,” Review of Economic Studies, 64, 311-335.

Jensen, R. (2004): “Do private transfers `displace' the benefits of public transfers? Evidence from South Africa” Journal of Public Economics 88(1), 89-112.

Kane, T. (1994): "College entry by blacks since 1970: the role of college costs, family background, and the returns to education," The Journal of Political Economy, 102(5), 878-911.

Keane, M. and Wolpin, K. (2001): "The effect of parental transfers and borrowing constraints on educational attainment," International Economic Review, 42(4), 1051-103.

Kochar, A. (1999): “Smoothing Consumption by Smoothing Income: Hours-of-Work Responses to Idiosyncratic Agricultural Shocks in Rural India,” Review of Economics and Statistics, 81, 50-61.

Lund, F. (1993): “State Social Benefits in South Africa.” International Social Security Review 46(1) pp. 5-25.

Lundberg, S. and R. Pollak (1993): "Separate spheres bargaining and the marriage market," Journal of Political Economy, 101.6:988-1010.

Lundberg, S., R. Pollak and T. Wales: (1997): "Do husbands and wives pool their resources? Evidence from the UK Child Benefit,” Journal of Human Resources, 32.3:463-80.

Morduch, J. (1994): "Poverty and Vulnerability," American Economic Review Papers and Proceedings 84, 221-225. 
Morduch, J. (1995): "Income Smoothing and Consumption Smoothing," Journal of Economic Perspectives 9, 103-114.

Morduch, J. (1999): "Between the State and the Market: Can Informal Insurance Patch the Safety Net," World Bank Research Observer, 14, 187-207.

Parker, J. A. (1999): “The Reaction of Household Consumption to Predictable Changes in Social Security Taxes,” American Economic Review, 89(4), 959-973.

Paulson, A. L. and R. Townsend (2001): "Entrepreneurship and Financial Constraints in Thailand," University of Chicago Manuscript.

Paxson, C. H. (1992): "Using Weather Variability to Estimate the Response of Savings to Transitory Income in Thailand,” American Economic Review, 82(1), 15-33.

Paxson, C. H. (1993): “Consumption and Income Seasonality in Thailand,” Journal of Political Economy, 101(1), February, 39-72.

Ranjan, P. (2001): “Credit Constraints and the Phenomenon of Child Labor,” Journal of Development Economics, 64, 81-102.

Schultz, T. W. (1960): "Capital Formation by Education," Journal of Political Economy, December, 571-583.

Souleles, N. S. (1999): “The Response of Household Consumption to Income Tax Refunds,” American Economic Review, 89(4), 947-958.

Souleles, N. S. (2002): “Consumer Response to the Reagan Tax Cuts,” Journal of Public Economics, 85, 99-120.

Thomas, D., Contreras, D., Frankenberg, E. (1999): "Distribution of Power Within the Household and Child Health.” UCLA Manuscript.

Townsend, R. (1995): "'Financial Systems in Northern Thai villages," Quarterly Journal of Economics 110(4), 1011-1046.

Willis, R. and Rosen, S. (1979): "Education and self-selection," Journal of Political Economy, 87(5), S7-36.

World Bank (2001): The 2001 World Bank Africa Database. Washington, D.C.: The World Bank.

Yang, D. (2003): "Remittances and Human Capital Investments: Child Schooling and Child Labor in the Origin Households of Oversees Filipino Workers," University of Michigan Manuscript. 


\begin{tabular}{|c|c|c|c|c|}
\hline & \multirow[t]{2}{*}{ Full Sample } & \multicolumn{2}{|r|}{$\begin{array}{ll} & \text { Person Age } \\
\text { th } & 50<=\text { Age }<=75 \\
5 & \text { But Not of } \\
& \text { Pension Age }\end{array}$} & $\begin{array}{l}\text { Person of } \\
\text { Pension Age }\end{array}$ \\
\hline & & 2 & 3 & 4 \\
\hline Sample Size & 6,482 & 3,503 & 1,456 & 1,296 \\
\hline Population & $5,327,912$ & 2,593,989 & $1,217,059$ & $1,300,116$ \\
\hline Age & 13.441 & 13.458 & 13.408 & 13.426 \\
\hline Sex & 0.521 & 0.525 & 0.508 & 0.523 \\
\hline \multicolumn{5}{|l|}{ Residency Attributes } \\
\hline Father Co-Resident & 0.347 & 0.412 & 0.419 & 0.183 \\
\hline Mother Co-Resident & 0.628 & 0.775 & 0.632 & 0.382 \\
\hline Grandfather Co-Resident & 0.099 & 0.006 & 0.106 & 0.249 \\
\hline Grandmother Co-Resident & 0.289 & 0.018 & 0.278 & 0.780 \\
\hline Child has not moved in last 2 years & 0.943 & 0.931 & 0.943 & 0.962 \\
\hline \multicolumn{5}{|l|}{ Hours in Child Labor in last 7 days } \\
\hline Total Hours & 15.586 & 14.856 & 17.074 & 15.790 \\
\hline Household Economic Activities & 7.023 & 6.890 & 7.386 & 7.030 \\
\hline Market Economic Activities & 8.563 & 7.965 & 9.689 & 8.760 \\
\hline \multicolumn{5}{|l|}{ Schooling in last 12 months } \\
\hline Currently Attend School & 0.961 & 0.960 & 0.957 & 0.961 \\
\hline Miss School for Work & 0.022 & 0.023 & 0.021 & 0.017 \\
\hline
\end{tabular}

All data are from the phase 2 of the Survey of the Activities of Young People, 1999.

Other than sample size, each cell contains the mean weighted to be representative of the South African population.

Primary school completion is only for children ages 13 and older

Having problems with cost of school and missing school for work is conditional on being currently in school 
Table 2A: Child Labor and Pension Eligibility

Dependent Variable: Total Hours Economically Active

\begin{tabular}{|c|c|c|c|c|c|c|c|c|c|c|c|c|}
\hline & 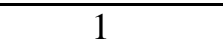 & & 2 & & 3 & & 4 & & 5 & & 6 & \\
\hline & OLS & & OLS & & OLS & & OLS & & OLS & & Tobit & \\
\hline Pension Eligible Female (PEF) & $-2.241(1.837)$ & & $-2.191(1.848)$ & & $-1.656(1.769)$ & & $-1.975(1.737)$ & & $-1.784(1.713)$ & & $-1.916(1.242)$ & \\
\hline Pension Eligible Male (PEM) & $-5.724(2.080)$ & ** & $-5.844(2.050)$ & $* *$ & $-5.873(2.156)$ & $* *$ & $-5.961(2.078)$ & ** & $-7.195(2.257)$ & $* *$ & $-6.016(1.837)$ & $* *$ \\
\hline $\mathrm{PEF} * \mathrm{PEM}$ & $3.021(2.965)$ & & 3.109 (2.979) & & 3.510 (2.839) & & $3.593(2.720)$ & & $3.948(2.813)$ & & $3.662(2.372)$ & \\
\hline Female & & & $0.592(0.686)$ & & $0.759(0.678)$ & & $0.897(0.682)$ & & $0.923(0.678)$ & & $1.062(0.634)$ & * \\
\hline \multicolumn{13}{|l|}{ Series in Age of Oldest Man and } \\
\hline Age of Oldest Woman & yes & & yes & & yes & & yes & & yes & & yes & \\
\hline Polynomial in Child Age & no & & yes & & yes & & yes & & yes & & yes & \\
\hline Province and Urban Fixed & no & & no & & yes & & yes & & yes & & yes & \\
\hline Housing Controls & no & & no & & no & & yes & & yes & & no & \\
\hline Household Composition & no & & no & & no & & no & & yes & & no & \\
\hline Adj R2 & 0.019 & & 0.030 & & 0.099 & & 0.122 & & 0.154 & & 0.013 & \\
\hline $\mathrm{N}$ & 2752 & & 2752 & & 2752 & & 2752 & & 2752 & & 2752 & \\
\hline
\end{tabular}

* significant at 10\%. ** Significant at 5\%. Standard errors (in parenthesis) corrected for clustering at the psu level and arbitrary heteroskedasticity.

All data are from the phase 2 of the Survey of the Activities of Young People, 1999.

All regressions also include a constant.

Series expansion is a third order series expansion in the age of the oldest male, the age of the oldest female, and all of their interactions.

The polynomial in child age is a third order polynomial.

Housing controls include indicators for the following: the dwelling is a house, hut, flat, or shack (other omitted) ; the dwellling has 1 room or 2 to 4 rooms (5 or more rooms omitted); the dwelling has electricity; the household cooks with wood; the household cooks with parafin; the household heats with wood; the household heats with parafin; the household gets water from a within dwelling tap; the household gets water from an on-site tap; the household gets water from a public tap; and the household cultivates land.

Household composition controls are a vector of dummies for the presence of a mother, a father, a grandparent, grandparents and parents, the number of household members 0-5, 6-9, 10-13, 14-17, 18-22, 22-49, 50-75, and 76 plus.

Urban fixed effects include formal urban, informal urban, and commercial farms (other rural) is the omitted group

Columns 1-5 are OLS. Column 6 is a tobit. R2 in column 6 is a pseudo-R2. 
Table 2B: Child Labor and Pension Eligibility with Artificial Treatment Variables

Dependent Variable: Total Hours Economically Active

\begin{tabular}{|c|c|c|c|c|c|c|c|}
\hline & 1 & 2 & 3 & 4 & & 5 & \\
\hline Pension Eligible Female (PEF) & & & & $-1.745(1.865)$ & & $-1.382(1.890)$ & \\
\hline Pension Eligible Male (PEM) & & & & $-6.298(2.405)$ & $* *$ & $-7.014(2.469)$ & ** \\
\hline $\mathrm{PEF} * \mathrm{PEM}$ & & & & 3.033 (2.989) & & 4.363 (3.113) & \\
\hline Woman Age 55 or greater (WA5) & $-0.484(1.772)$ & & & $-0.119(1.876)$ & & $-0.765(1.850)$ & \\
\hline Man Age 60 or greater (MA6) & $-0.024(2.082)$ & & & $1.239(2.280)$ & & $1.370(2.303)$ & \\
\hline WA5*MA6 & $2.195(2.511)$ & & & $1.805(2.625)$ & & $1.292(2.636)$ & \\
\hline Woman Age 65 or greater (WA6) & & $-0.547(2.451)$ & & & & $2.247(2.472)$ & \\
\hline Man Age 70 or greater (MA7) & & $-2.621(1.728)$ & & & & $-2.089(1.725)$ & \\
\hline WA6*MA7 & & $-4.431(3.580)$ & & & & $-6.092(3.717)$ & \\
\hline Woman Age 65 or greater (WA6) & & & $-2.344(1.863)$ & & & & \\
\hline Man Age 60 or greater (MA6) & & & 0.987 (1.669) & & & & \\
\hline WA6*MA6 & & & $-3.112(2.970)$ & & & & \\
\hline Female & $0.766(0.688)$ & $0.854(0.678)$ & $0.835(0.677)$ & $0.799(0.682)$ & & $0.914(0.682)$ & \\
\hline \multicolumn{8}{|l|}{ Series in Age of Oldest Man and } \\
\hline Age of Oldest Woman & yes & yes & yes & yes & & yes & \\
\hline Polynomial in Child Age & yes & yes & yes & yes & & yes & \\
\hline Province and Urban Fixed & yes & yes & yes & yes & & yes & \\
\hline Adj R2 & 0.095 & 0.098 & 0.098 & 0.100 & & 0.103 & \\
\hline $\mathrm{N}$ & 2752 & 2752 & 2752 & 2752 & & 2752 & \\
\hline
\end{tabular}

* significant at 10\%. ** Significant at 5\%. Standard errors (in parenthesis) corrected for clustering at the psu level and arbitrary heteroskedasticity.

All regressions also include a constant.

Series expansion is a third order series expansion in the age of the oldest male, the age of the oldest female, and all of their interactions.

The polynomial in child age is a third order polynomial.

All Columns are OLS. All data are from the phase 2 of the Survey of the Activities of Young People, 1999. 
Table 3: Pension Eligibility and School Attendence

Probit Results, Marginal Effects Reported

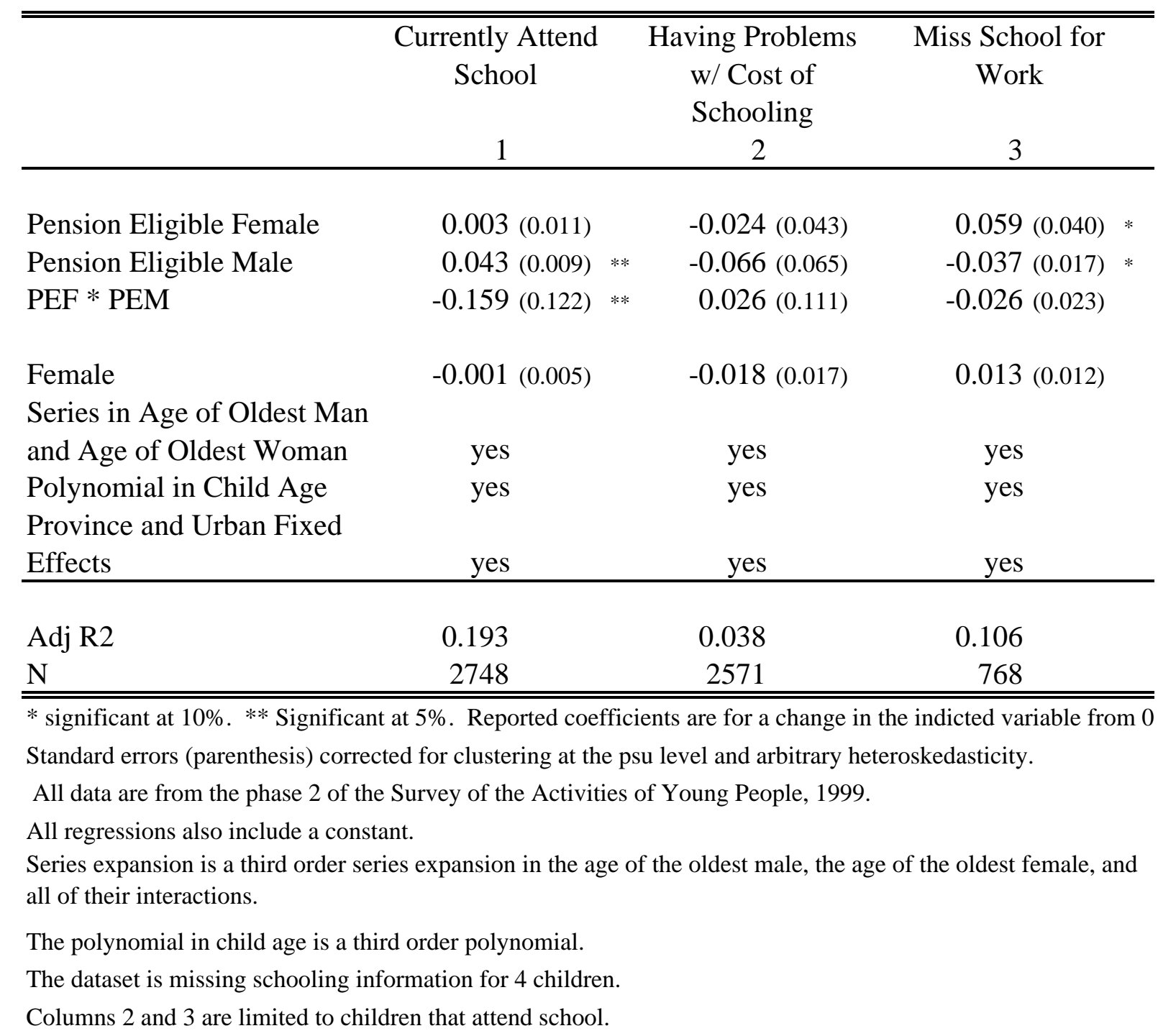


Table 4: Child Labor and Pension Eligibility

Dependent Variable: Total Hours in Market and Household Economic Activities

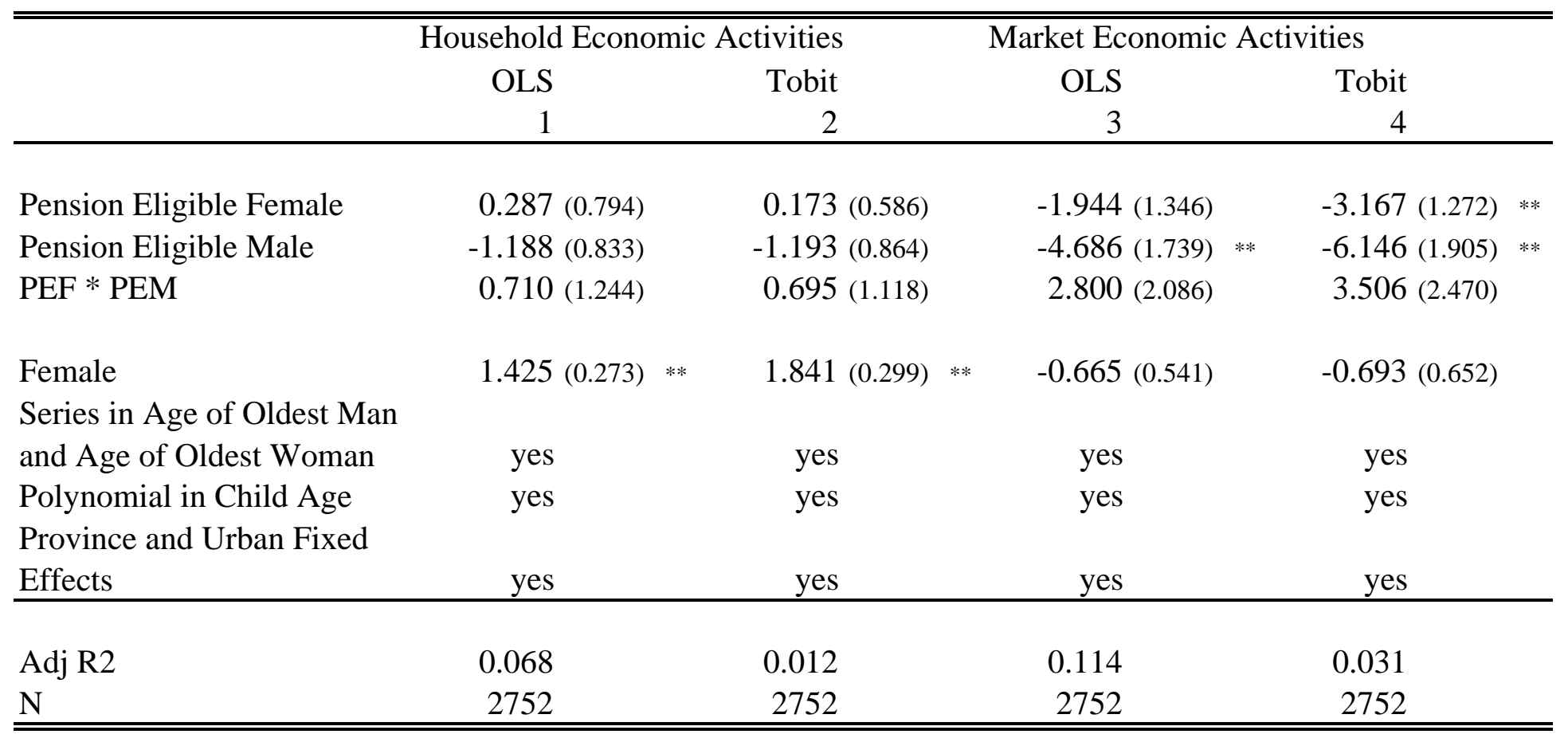

* significant at $10 \%$. ** Significant at $5 \%$.

All data are from the phase 2 of the Survey of the Activities of Young People, 1999.

Standard errors (parenthesis) corrected for clustering at the psu level and arbitrary heteroskedasticity.

All regressions also include a constant.

Series expansion is a third order series expansion in the age of the oldest male, the age of the oldest female, and all of their interactions.

The polynomial in child age is a third order polynomial.

Columns 1 and 3 are OLS. Columns 2 and 4 are tobits: a pseudo-R2 is reported. 
Table 5: Elder Education, Pension Eligibility, Child Labor, and School Attendence

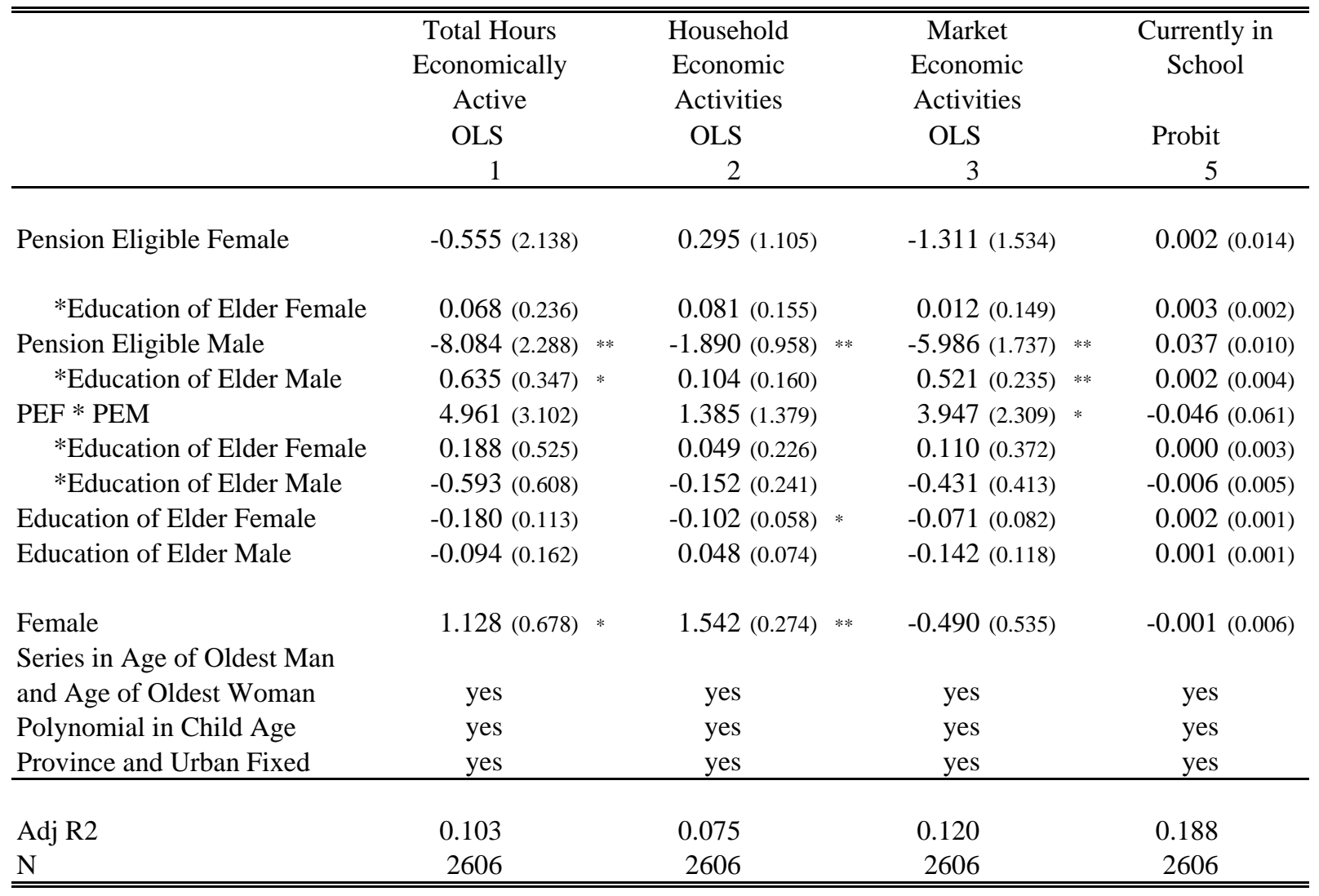

* significant at 10\%. ** Significant at 5\%. Reported coefficients are for a change in the indicted variable from 0 to 1.

All data are from the phase 2 of the Survey of the Activities of Young People, 1999.

Standard errors corrected for clustering at the psu level and arbitrary heteroskedasticity.

All regressions also include a constant.

Series expansion is a third order series expansion in the age of the oldest male, the age of the oldest female, and all of their interactions.

The polynomial in child age is a third order polynomial.

Marginal effects reported for probits. 
Appendix Table A1: Means of Household Characteristics for black headed households with children 10.

\begin{tabular}{|c|c|c|c|c|c|}
\hline \multirow[t]{4}{*}{ Sample } & \multirow{4}{*}{$\begin{array}{c}\text { Phase } 1 \\
\\
\\
\\
1 \\
\end{array}$} & \multicolumn{4}{|c|}{ Phase 2} \\
\hline & & & \multirow[b]{2}{*}{$\begin{array}{c}\text { No Person in } \\
\text { HH with } \\
\text { Age }>=50 \text { to } 75\end{array}$} & \multicolumn{2}{|c|}{$\begin{array}{c}\text { Households with } \\
\text { person } 50 \text { to } 75\end{array}$} \\
\hline & & & & $\begin{array}{c}\text { No Person } \\
\text { of Pension } \\
\text { Age }\end{array}$ & $\begin{array}{c}\text { Person of } \\
\text { Pension } \\
\text { Age }\end{array}$ \\
\hline & & 2 & 3 & 4 & 5 \\
\hline Sample Size & 10,480 & 3,685 & 2,208 & 785 & 692 \\
\hline Population & $3,743,031$ & $1,250,500$ & 712,507 & 271,742 & 266,251 \\
\hline Urban & 0.462 & 0.488 & 0.532 & 0.462 & 0.398 \\
\hline Household Size & 6.016 & 5.982 & 5.322 & 6.473 & 7.245 \\
\hline Number of Children 0-17 & 3.110 & 3.101 & 2.942 & 3.125 & 3.502 \\
\hline Number of Children 10-17 & 1.760 & 1.784 & 1.715 & 1.847 & 1.905 \\
\hline Number of Persons 50 or greater & 0.647 & 0.614 & 0.062 & 1.211 & 1.483 \\
\hline Number of Pension Eligible Individuals & 0.319 & 0.293 & 0.062 & & 1.209 \\
\hline Qualify for Phase 2 & 0.740 & & & & \\
\hline Age of Oldest Female & 46.308 & 45.628 & 37.412 & 48.675 & 64.508 \\
\hline Age of Oldest Male & 34.324 & 34.096 & 28.526 & 40.312 & 42.656 \\
\hline Pension Eligible Female in the & & & & & \\
\hline Household & 0.230 & 0.209 & 0.045 & & 0.863 \\
\hline Pension Eligible Male in the Household & 0.079 & 0.077 & 0.017 & & 0.314 \\
\hline $\begin{array}{l}\text { Both Pension Eligible Female and Male } \\
\text { in the Household }\end{array}$ & 0.045 & 0.040 & 0.005 & & 0.177 \\
\hline Household Recieves Pension Income & 0.257 & 0.237 & 0.069 & 0.132 & 0.793 \\
\hline Dwelling is a House & 0.555 & 0.546 & 0.546 & 0.533 & 0.560 \\
\hline Dwelling is a Hut & 0.237 & 0.215 & 0.177 & 0.250 & 0.280 \\
\hline Dwelling is a Shack & 0.145 & 0.171 & 0.200 & 0.150 & 0.118 \\
\hline Dwelling is a Flat & 0.020 & 0.026 & 0.035 & 0.023 & 0.005 \\
\hline One Room Dwelling & 0.061 & 0.071 & 0.090 & 0.055 & 0.036 \\
\hline Two - Four Room Dwelling & 0.564 & 0.564 & 0.597 & 0.534 & 0.504 \\
\hline Dwelling has electricity & 0.626 & 0.633 & 0.659 & 0.601 & 0.594 \\
\hline Cook with Fire & 0.327 & 0.310 & 0.258 & 0.344 & 0.416 \\
\hline Cook with Parafin & 0.206 & 0.225 & 0.230 & 0.223 & 0.216 \\
\hline Heat with Fire & 0.355 & 0.341 & 0.292 & 0.378 & 0.437 \\
\hline Heat with Parafin & 0.171 & 0.195 & 0.197 & 0.195 & 0.189 \\
\hline Water in house & 0.252 & 0.248 & 0.262 & 0.255 & 0.205 \\
\hline Water on Site & 0.253 & 0.263 & 0.277 & 0.236 & 0.253 \\
\hline Uses Public Water Tap & 0.227 & 0.240 & 0.236 & 0.255 & 0.235 \\
\hline Cultivate Land & 0.364 & 0.362 & 0.318 & 0.382 & 0.461 \\
\hline
\end{tabular}




\section{Appendix Table A2: Pension Eligibility and the Co-habitation of Children and Elderly}

Dependent Variable: Number of co-resident children between 10 and 17

Household level regressions - conditional on having an elder, age 50 to 75

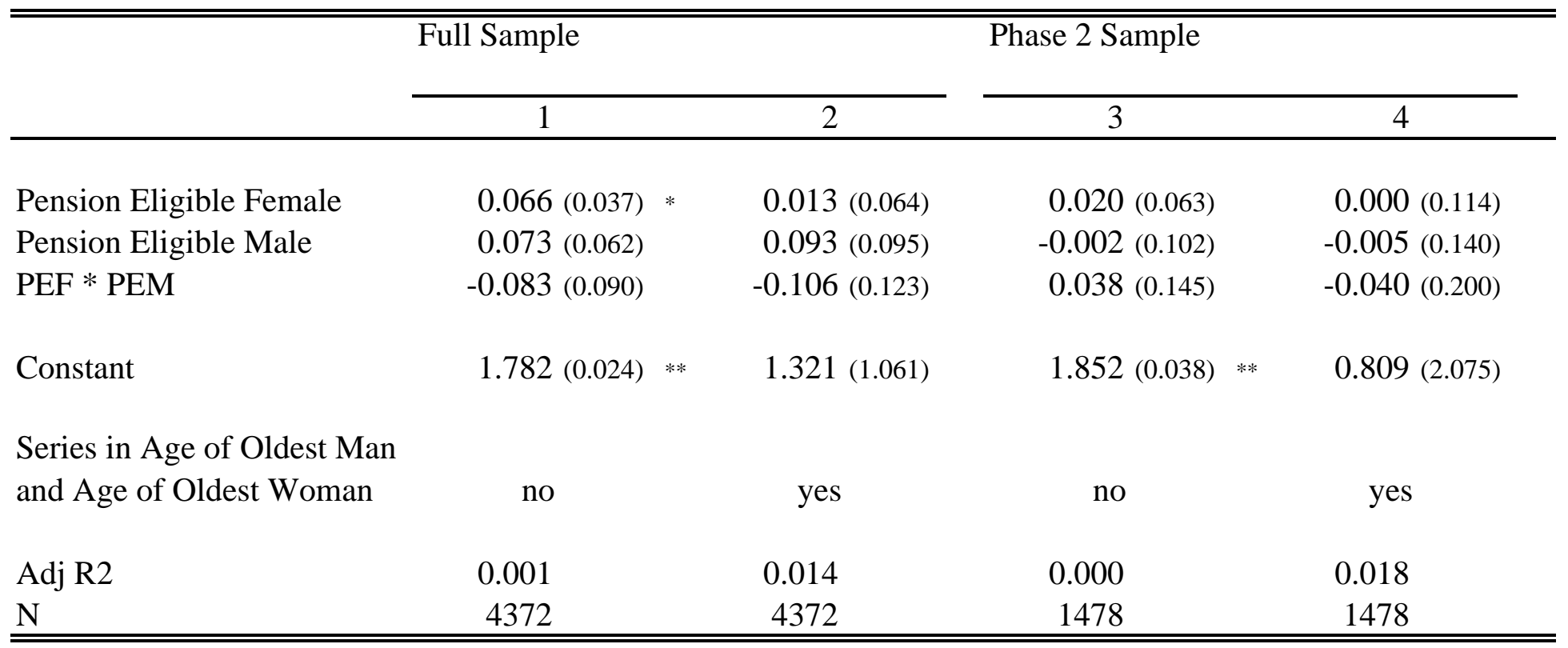

* significant at 10\%. ** Significant at 5\%. Reported coefficients are for a change in the indicted variable from 0 to 1.

All data in columns $1 \& 2$ are from the phase 1 of the Survey of the Activities of Young People, 1999. Columns 3 \& 4 are from phase 2. Standard errors (parenthesis) corrected for clustering at the psu level and arbitrary heteroskedasticity.

Series expansion is a third order series expansion in the age of the oldest male, the age of the oldest female, and all of their interactions.

All regressions also include a constant 
Appendix Table A3: Pension Eligibility, Child Labor, and School Attendence for Stationary Children

Regressions limited to children that have not moved within the last two years

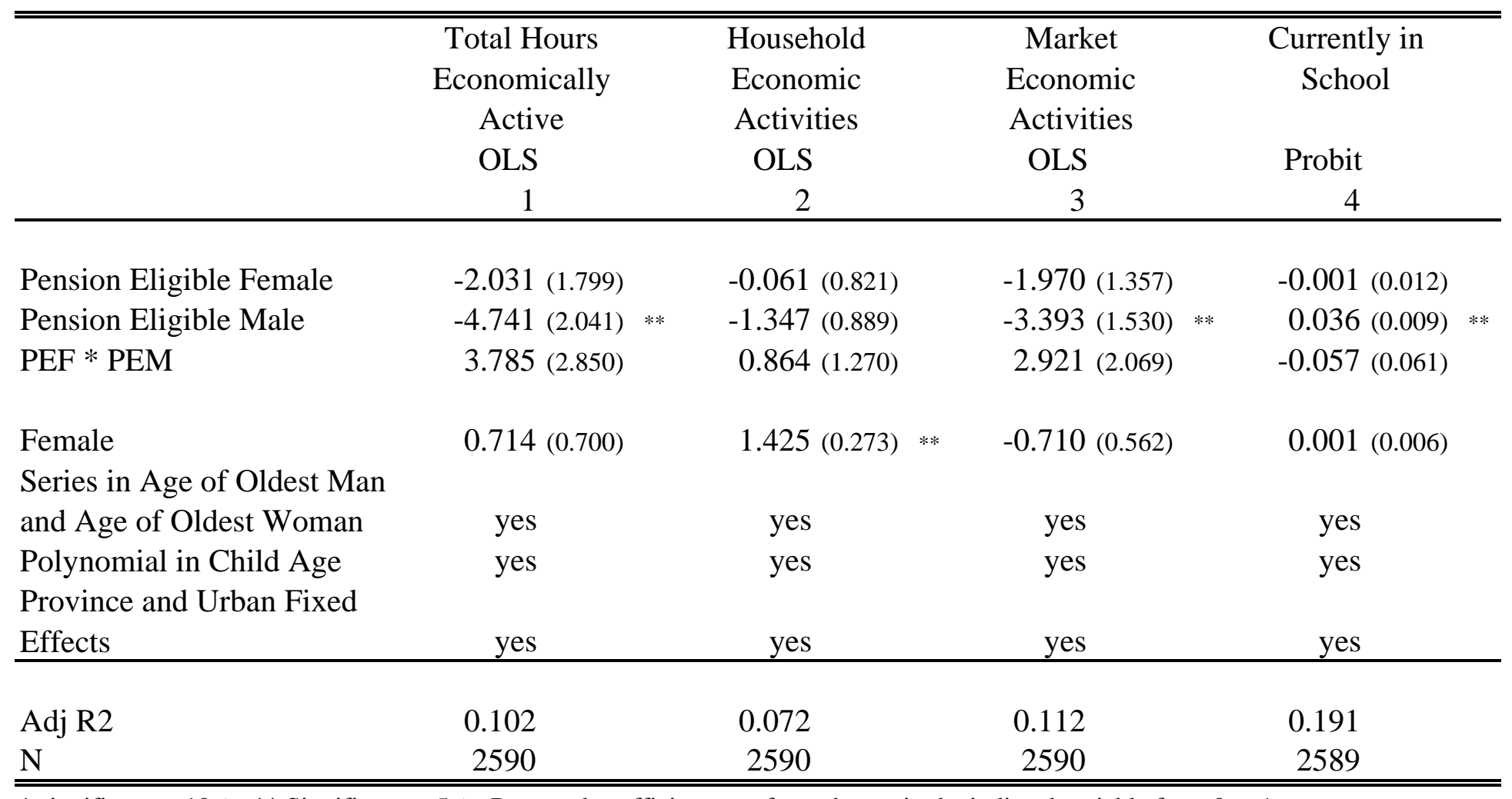

* significant at 10\%. ** Significant at 5\%. Reported coefficients are for a change in the indicted variable from 0 to 1.

All data are from the phase 2 of the Survey of the Activities of Young People, 1999.

Standard errors corrected for clustering at the psu level and arbitrary heteroskedasticity.

All regressions also include a constant.

Series expansion is a third order series expansion in the age of the oldest male, the age of the oldest female, and all of their interactions.

The polynomial in child age is a third order polynomial.

Marginal effects reported for probits. 
Appendix Table A4: Household Composition Controls and the Efficiency of Child Labor Percentage Change in Estimated Regression Coefficients after Partialling Out Household Composition

\begin{tabular}{|c|c|c|c|c|}
\hline & $\begin{array}{c}\text { Total Hours } \\
\text { Economically } \\
\text { Active } \\
1\end{array}$ & $\begin{array}{l}\text { Household } \\
\text { Economic } \\
\text { Activities } \\
2\end{array}$ & $\begin{array}{c}\text { Market } \\
\text { Economic } \\
\text { Activities } \\
3\end{array}$ & $\begin{array}{c}\text { Currently in } \\
\text { School } \\
4\end{array}$ \\
\hline \multicolumn{5}{|l|}{ Pension Eligible Female } \\
\hline$\% \Delta$ in $\beta$ & -0.519 & 0.958 & -0.301 & -0.705 \\
\hline P-Value for H0: $\Delta=0$ & 0.606 & 0.717 & 0.645 & 0.749 \\
\hline $\mathrm{P}-\mathrm{V}$ alue for $\mathrm{H} 0: \beta 2=0$ & 0.633 & 0.459 & 0.286 & 0.893 \\
\hline \multicolumn{5}{|l|}{ Pension Eligible Male } \\
\hline$\% \Delta$ in $\beta$ & -0.062 & -0.049 & -0.065 & -0.209 \\
\hline P-Value for $\mathrm{H} 0: \Delta=0$ & 0.869 & 0.944 & 0.865 & 0.429 \\
\hline P-Value for $\mathrm{H} 0: \beta 2=0$ & 0.012 & 0.174 & 0.015 & 0.003 \\
\hline \multicolumn{5}{|l|}{$\mathrm{PEF} * \mathrm{PEM}$} \\
\hline$\% \Delta$ in $\beta$ & 0.032 & -0.015 & 0.044 & -0.322 \\
\hline P-Value for H0: $\Delta=0$ & 0.968 & 0.993 & 0.953 & 0.662 \\
\hline $\mathrm{P}-\mathrm{Value}$ for $\mathrm{H} 0: \beta 2=0$ & 0.198 & 0.563 & 0.161 & 0.357 \\
\hline
\end{tabular}

First stage regressions follow the specification used throughout tables 4-7.

All data are from the phase 2 of the Survey of the Activities of Young People, 1999.

The second stage regressions are in two steps. First, the indicated dependent variable is regressed on household composition controls. The residuals from this first step are then regressed on the regression specificication used in the first stage.

The row "\% $\Delta$ in $\beta$ " contains the percentage change in the indicated regression coefficient in the second step of the second stage, treating the first stage regression as the baseline.

The row "P-Value for H0: $\Delta=0$ " contains the P-Value for the null hypothesis that that the change in regression coefficients between the first and second stage is zero.

The row " P-Value for H0: $\beta 2=0$ " contains the P-Value for the null hypothesis that that the coefficient on the indicated coefficient in the second step of the second stage is zero.

Household composition controls are a vector of dummies for the presence of a mother, a father, a grandparent, grandparents and parents, the number of household members 0-5, 6-9, 10-13, 14-17, 18-22, 22-49, 50-75, and 76 plus. 